\title{
Tomasz Flasiński
}

\section{„Marzy mi się Lew Boży". Kryzys ustrojowy w Pakistanie 1953-1955}

\begin{abstract}
Abstrakt: Artykuł omawia przesilenie ustrojowe w Pakistanie, które trwało w latach 19531955 i zakończyło się praktyczną likwidacją ustroju demokratycznego w tym państwie. Władza wykonawcza (gubernator generalny) w sojuszu z sądowniczą (Sąd Najwyższy) i wojskiem odrzuciła przejęte po Brytyjczykach niepisane zasady regulujące parlamentaryzm, a w końcu rozpędziła i sam parlament. W ostatecznym rozrachunku droga ta powiodła kraj ku autokracji.
\end{abstract}

Słowa kluczowe: Pakistan, system westminsterski, Hans Kelsen.

Abstract: The article describes the crisis of Pakistani policy between 1953 and 1955, which resulted de facto in the liquidation of democracy. The executive power (Governor-General) allied with the judicial one (Supreme Court) and the army to get rid of the unwritten principles, taken over from the British, regulating the parliamentary order, and finally dissolved the Parliament itself. Ultimately, it led the country to autocracy.

Keyw ords: Pakistan, Westminster system, Hans Kelsen.

12 VII 1967 r. do willi Mohammada Ayuba Khana w górskim kurorcie Murree przyszedł na kolację Muhammad Munir. Pierwszy z wymienionych, od dziewięciu lat - dokładniej od 27 X 1958 r., gdy obalił swego poprzednika Iskandra Mirzę - sprawujący dyktatorską władzę nad Pakistanem, powoli tracił w kraju mir po niedawnej, przegranej wojnie z Indiami; drugi, w 1962 r. minister prawa w jego rządzie, a przedtem (1954-1960) prezes Sądu Najwyższego, był już politycznym emerytem, gnębionym przez choroby. Konwersacja zeszła na temat, o którym w tej sytuacji obaj panowie mogli już rozmawiać zupełnie szczerze: zamach stanu Iskandra Mirzy, który 8 X 1958 r. 
korzystając ze swoich uprawnień jako prezydent, wprowadził stan wojenny, rozwiązał parlament i zawiesił konstytucję. Ayub wyznał, że zawsze podejrzewał Munira o namówienie Mirzy do tego kroku: ekssędzia zaprzeczył, dodając, iż w istocie „doradził [...] Mirzy, by ten zezwolił na wybory, po czym rozpanoszyłby się nieunikniony chaos. Wtedy byłby on w lepszej pozycji i z dogodniejszą furtką dla ogłoszenia stanu nadzwyczajnego"1. To nader istotne stwierdzenie - świat poznał je dopiero w 2007 r. po opublikowaniu dzienników Ayuba - pokazuje nie tylko, jak wiele ważnych a przełomowych odkryć może jeszcze czekać badaczy we wciąż trudno dostępnych pakistańskich źródłach, ale też stanowi przyczynek do odpowiedzi, dlaczego pierwsza demokracja pakistańska (1947-1958) poniosła klęskę, kończąc się zamachem stanu. Tak Munir, jak Ayub odegrali istotną rolę w kryzysie politycznym lat 1953-1955; przed nimi kraj, choć średnio stabilny, podążał w kwestiach ustrojowych droga z grubsza podobną do sasiednich Indii, wyszedł z niego zaś z całkowicie zaburzonym trójpodziałem władzy i armią rozdająca karty w polityce. Na czym polegała ta przemiana i czemu do niej doszło?

Wypada na początku przypomnieć, że utworzone formalnie 15 VIII $1947 \mathrm{r}$. państwo, nad którym władzę obją jego polityczny twórca Muhammad Ali Jinnah zwany przez zwolenników Quaid-i-Azamem (,Wielkim Przywódca”) i partia tegoż - Liga Muzułmańska, od początku borykało się z szeregiem arcytrudnych wyzwań. Pakistan Zachodni (z grubsza odpowiadający obecnemu) i znacznie biedniejszy Wschodni (Bengal Wschodni, dzisiejszy Bangladesz) ${ }^{2}$ dzieliło $2500 \mathrm{~km}$ w prostej linii, z wszystkimi tego negatywnymi konsekwencjami natury logistycznej i gospodarczej. Pięć razy mniejszy wschód zamieszkiwało 55,5\% mieszkańców kraju, niemal wyłącznie Bengalczyków, co mocno różniło ten region od mozaiki etnicznej czterech prowincji zachodu. Język urdu, który w marzeniach Jinnaha miał stanowić lingua franca Pakistanu, znało tylko 7,2\% mieszkańców kraju, w tym ledwie 0,1\% Bengalczyków ${ }^{3}$. Pomijając już ludy zachodnich kresów (np. Beludżów), często otwarcie wrogie Pakistanowi, również wśród reszty mieszkańców identyfikacja z nowym państwem nie była wielka ${ }^{4}$. Przedtem ich elity jednoczył (i to tylko częściowo)

${ }^{1}$ Diaries of Field Marshal Mohammad Ayub Khan, 1966-1972, ed. C. Baxter, Karachi 2007, s. 116.

${ }^{2}$ Nazwa „Pakistan Wschodni” została oficjalnie wprowadzona w roku 1955 . W celach stylistycznych będę jej używał także odnośnie do okresu wcześniejszego.

${ }^{3}$ Dane za: J. Das Gupta, Official Language Problems and Policies in South Asia, w: Current Trends in Linguistics, vol. V: Linguistics in South Asia, ed. Th.A. Sebeok, Hague-Paris 1969, s. 581.

${ }^{4}$ Dodać można, że wedle spisu powszechnego z 1951 r. - już po przemieszczeniach ludności w czasach podziału i po pogromie w Bengalu Wschodnim w 1950 r. - hinduiści stanowili 14\% mieszkańców Pakistanu jako całości, a 23\% - Bengalu Wschodniego. The Constituent Assembly of Pakistan Debates: Official Report (dalej: CAP), sixteenth session, 19 VIII 1954, s. 267. Wszystkie przypisy dotyczące obrad parlamentu odnoszą się do sesji „konstytucyjnych”, poświęconych pracom nad ustawą zasadnicza, których numeracja była inna od sesji 
nie tyle islam, co poczucie politycznego, a niekiedy fizycznego zagrożenia ze strony hinduistów i zdominowanej przez nich Partii Kongresu; po podziale subkontynentu spoiwo to znikło. Z Pakistanem utożsamiali się za to szacowani co do liczby na $7 \mathrm{mln}$ muzułmańscy migranci z Indii (na zachodzie zwani zwykle mohadizirami, na wschodzie - Biharczykami, od jednej z prowincji pochodzenia ${ }^{5}$ ), ale ich napływ wygenerował szereg konfliktów z dotychczasowymi mieszkańcami ziem, gdzie przybywali, a ich integracja nigdzie w istocie nie zakończyła się sukcesem - rzecz do przewidzenia w kulturze tak dalece skoncentrowanej na korzeniach i postrzegającej ludzi przez pryzmat ich grupy. Już za następcy Quaid-i-Azama konflikty, w których personalne ambicje polityków krzyżowały się z przynależnością frakcyjna, etniczną i klanowa, miały regularnie podminowywać stabilność państwa na każdym poziomie.

W tej trudnej sytuacji Jinnah posiadał przynajmniej jeden ważny atut: niekwestionowany mandat do rządzenia przy praktycznym braku opozycji. Nad Pakistańską Liga Muzułmańską - spadkobierczynią Ligi z czasów kolonialnych - nie sprawował wprawdzie kontroli absolutnej ${ }^{6}$, ale o otwartym sprzeciwie wobec niego mowy nie było, zaś niemałe ongi wpływy Partii Kongresu w Północno-Zachodniej Prowincji Granicznej czy głoszących współprace międzywyznaniową tzw. unionistów w Pendżabie przepadły w pożodze walk religijnych. Na wschodzie ewentualnych problemów mógł przysporzyć zręczny i lubiany centrolewicowiec Hussein Shaheed Suhrawardy (ostatni premier Bengalu przed podziałem), nad którym mimo jego członkostwa w Lidze Quaid-i-Azam nigdy do końca nie zapanował. Podział Indii pozbawił go jednak bazy w rodzinnej Kalkucie, a włączenie do Pakistanu Wschodniego asamskiego dystryktu Sylhet przysporzyło wrogów w osobach wpływowych tam obszarników; mierząc się również z niechęcią Jinnaha przegrał walkę o premierostwo Pakistanu Wschodniego ze swym wielkim rywalem, bezbarwnym konserwatystą Khawają Nazimuddinem. Z polityki pakistańskiej początkowo zresztą wyłączył się w ogóle, próbując budować muzułmańską opozycję w indyjskim Bengalu Zachodnim (co Pakistan w dobie walk z Indiami piętnował jako zdradę). Nie zagrażali tė̇ Jinnahowi ulemowie - teolodzy islamscy ${ }^{7}$.

„zwykłych”, a ich protokoły ukazywały się w osobnych tomach. Ponieważ jedne i drugie sa obecnie dostępne w Internecie (http://www.na.gov.pk/en/debates.php), nie powinno to stanowić problemu dla czytelnika.

${ }^{5}$ Nazwy te, gwoli klarowności, nie dotyczyły Bengalczyków i Pendżabczyków, którzy przenosili się z indyjskiej do pakistańskiej części swej prowincji; muzułmanina wyjeżdżającego np. z Kalkuty do Dakki nikt nie miał za „Biharczyka”, był po prostu swojakiem, który się przeprowadził ze względów politycznych.

${ }^{6}$ Zob. A. Jalal, The State of Martial Rule. The Origins of Pakistan's Political Economy of Defence, Lahore 1991, s. 61 (mimo pewnej liczby drobnych błędów i kontrowersyjnych sądów to zdecydowanie najlepsze opracowanie na temat pierwszej demokracji pakistańskiej).

${ }^{7}$ Szczególnie szanowanych i uczonych ulemów zwano mawlanami, nauczycielami. Natomiast popularny termin „mułła”, teoretycznie synonim ulema, na subkontynencie nabrał cech obelgi, jak polski „klecha”. 
Radykałowie $\mathrm{z}$ tego grona, skupieni w takich organizacjach, jak Jamaat-e-Islami (JI) czy tzw. ruch ahrarów, uważając postulaty Ligi za zbyt mało islamskie, przez lata bowiem współpracowali z Partia Kongresu, w efekcie zaś po utworzeniu Pakistanu na pewien czas znaleźli się na cenzurowanym - choć ostracyzm ten wygasł już pod koniec lat czterdziestych; świat zmieniał się tak szybko, że czasy sprzed podziału rychło stały się dla wszystkich „historią starożytną".

Jinnah korzystał też z ogromnych uprawnień funkcji gubernatora generalnego (które ostatni brytyjski wicekról Louis Mountbatten, mający nadzieję objać to stanowisko w obu państwach sukcesyjnych Indii Brytyjskich, skroił pod siebie). Poza innymi prerogatywami mógł on wydawać dekrety - w latach 1947-1956 podpisano takich 376 wobec 160 promulgowanych przez parlament ustaw. Sam też został przewodniczacym parlamentu, premierostwo przypadło zaś jego prawej ręce, Liaquatowi Alemu Khanowi. W tych warunkach twórca Pakistanu mógł przynajmniej na szczeblu centralnym zabrać się za wcielanie w życie swojej wizji państwa.

Nie było jednak i nie jest całkiem jasne, jaka to wizja. Polityków wypada sązić przede wszystkim po czynach, nie po słowach: zbyt wielu czynów zaś, rządząc stworzonym przez siebie krajem rok (teoretycznie nieco dłużej, ale ostatnie miesiace upłynęły mu na walce z choroba), Quaid-i-Azam dokonać nie zdążył, a interpretacja tych, które miały miejsce, jest w tym kontekście niezwykle trudna. Pomijając nawet beznadziejnie uwikłaną we współczesne konteksty polityczne kłótnię, czy Jinnahowa wizja państwa była „świecka”, czy „islamska”, sztandarowy przykład stanowi spór o miejsce języka bengalskiego w państwie, wywołany dążeniem Karaczi do siłowego narzucania urdu. „Wielki Przywódca” uznał w końcu za stosowne wybrać się do Dakki i publicznie zwymyślać malkontentów jako zdrajców ojczyzny na indyjskim żołdzie, ale w późniejszym okresie nigdy już nie podjął tematu. Czy zmienił zdanie, czy też przekonawszy się o sile przeciwników urdu, wybrał milczenie, nie wiadomo - i dzięki temu w późniejszym okresie na Jinnaha mogły się powoływać wszystkie strony kłótni o status bengalszczyzny.

W tym kontekście nie ulegaja za to wątpliwości dwie inne sprawy. Po pierwsze, remedium na najważniejsze problemy Quaid-i-Azam widział

\footnotetext{
${ }^{8}$ Określenie Stephena Hatcha-Barnwella, w popodziałowym Pakistanie komisarza jednego $\mathrm{z}$ dystryktów. S. Hatch-Barnwell, The Last Guardian. Memoirs of Hatch-Barnwell, ICS of Bengal, Dhaka 2011, s. 350.

${ }^{9} \mathrm{~W}$ obecnej chwili ostatnim jej słowem jest sugerująca drugą interpretację, warta uwagi praca Saleeny Karim, Secular Jinnah \& Pakistan. What The Nation Doesn't Know, Karachi 2010. Dalsza bibliografia tamże oraz w moim tekście Wspominanie deszczu. Dyskurs na temat dziejów pierwszej demokracji pakistańskiej (1947-1958) jako pole walki o wspótczesna wizję państwa (przygotowywany do druku w materiałach pokonferencyjnych IV Międzynarodowego Kongresu Azjatyckiego w Toruniu), w którym rozwijam zaledwie tu zasygnalizowany wątek roli religii w politycznych sporach omawianego okresu.
} 
w angażowaniu własnego autorytetu. Dzierżąc dwa z trzech najważniejszych stanowisk w państwie, mógł przy tym pomijać parlament i rząd - Liaquat, nawykły do subordynacji wobec wodza, nie protestował. Po drugie, moc sprawcza „Wielkiego Przywódcy” była bardziej ograniczona, niż nadal wydaje się jego chwalcom i niż początkowo mniemał on sam. Nie udało mu się np. skłonić do ustapienia pendżabskiego premiera z własnej partii, nawaba Mamdotu, którego chciał się pozbyć; mógł go rzecz jasna zdymisjonować, ale rozwiąanie tej sprawy siła pogłębiłoby chaos w prowincji, a odwołany premier zapewne pociagnałby za sobą znaczną część tamtejszej Ligi ${ }^{10}$.

Po zgonie Jinnaha (11 IX 1948 r.) nikt nie kwestionował sukcesji Liaquata. Inaczej niż poprzednik nowy przywódca wolał rządzić z premierowskiego fotela, urząd gubernatora generalnego powierzając Nazimuddinowi, słusznie uznawanemu za figuranta ${ }^{11}$. Czynił to zapewne w perspektywie przyjęcia wcześniej lub później konstytucji, w której to premier, a nie głowa państwa, miałby pozycję najsilniejszą. Choć jednak podobnie jak w przypadku Quaid-i-Azama to osoba Liaquata czyniła swe stanowisko głównym ośrodkiem władzy, a nie odwrotnie, nie dorównywał on swemu mistrzowi autorytetem (także wśród ministrów, których jako nominatów tamtego niezręcznie mu było wymieniać). Brak ten próbował zrównoważyć częstszym stosowaniem siły i nie jest chyba przypadkiem, że po ledwie kwartale posuną się do kroku, przed którym Jinnah wzdragał się do końca: odwołał rząd nawaba Mamdotu, wprowadzając w Pendżabie autokratyczne rządy gubernatorskie. Innym poręcznym narzędziem szefa rządu stała się wydana 6 I 1949 r. tzw. PRODA (Public and Representative Office Disqualification Act), osławiona ustawa mierzaca w winnych „nieodpowiedniego postępowania [misconduct]”. Cóż to znaczyło? Dość sporo, a przy tym użyte sformułowania nie były jasne. Przytaczam tylko część obszernej definicji: „W pojęciu tym zawiera się przekupstwo, korupcja, nieuczciwe czerpanie zysków z pełnionej funkcji [jobbery], faworytyzm, nepotyzm, celowo złe zarządzanie, celowo niewłaściwe wykorzystanie lub alokacja środków publicznych [...] oraz jakiekolwiek inne nadużycie władzy lub stanowiska, względnie podżeganie do wymienionych czynów"12. Na mocy tej ustawy gubernator generalny i gubernatorzy prowincji mogli wszczynać postępowania przeciw piastunom urzędów oraz posłom; mieli oczywiście prawo inicjatywy, ale wnioskować o taki krok mógł też każdy obywatel, który złożył depozyt w wysokości 5 tys. rupii. Udowodnienie zarzutów skutkowało dziesięcioletnim zakazem pełnienia funkcji publicznych. Trzeba jednak przyznać, że sądy, wciąż cieszące się w kraju sporym mirem,

\footnotetext{
10 A. McGrath, The Destruction of Pakistan's Democracy, Karachi-Oxford 1998, s. 47-51.

${ }_{11}$ Premierostwo Bengalu Wschodniego przeją po tym ostatnim Nurul Amin.

12 Tekst PRODA za: National Archives, Kew (dalej: NA), DO 35/5114, s. 11, załącznik. Zob. też zapis dość kuriozalnej debaty parlamentarnej na temat przyjęcia tej ustawy: CAP, fourth session, 6 I 1949, s. 43-69.
} 
nie przejawiały chęci pracy na polityczne zamówienie; wybroniło się przed nimi sporo ludzi oskarżonych z PRODY, m.in. nawab Mamdotu. Niemniej już sama groźba kosztownych bojów sądowych była skutecznym straszakiem, tym bardziej że PRODA nie zobowiązywała władz do upubliczniania w mediach decyzji uniewinniających.

Prócz korupcji PRODA zwalczać miała aktywność antypaństwową i „komunizm”. Ten ostatni był w 95\% wymysłem władz - częściowo świadomym, częściowo nie. Wrzucając do worka z tym napisem i ruchy chłopskie, i demonstracje studenckie żądające przestrzegania praw obywatelskich, i dziennikarzy poddających pod rozwagę sojusz z Moskwa jako antidotum na wstrzemięźliwość ONZ w sprawie konfliktu o Kaszmir, w wygodny sposób dezawuowano rzeczywiste postulaty i argumenty niezadowolonych. A jednocześnie wydaje się, iż Liga - w latach 1946/1947 nawykła do powszechnego poparcia ze strony muzułmanów - jak wiele jej podobnych organizacji roiła sobie, że zostanie tak już na zawsze. Fakt, że w niepodległym Pakistanie ludzie wychodzą na ulice w sprzeciwie wobec grupy, która im ten kraj dała, był dla Ligi ewidentnym szokiem, a wpływy ciemnych sił inspirowanych przez ZSRR lub Indie wygodnym wyjaśnieniem - tym sposobem partia Liaquata nie musiała rozliczać się $\mathrm{z}$ własnymi wadami ${ }^{13}$.

Kto wie, czy nie jest to jeden z najważniejszych kluczy do sprawy tzw. spisku z Rawalpindi, który wyszedł na jaw w roku 1950; grupa oficerów, z szefem sztabu armii na czele, chciała przejąć władzę, pojmawszy Liaquata i Nazimuddina podczas wizyty w pendżabskim Rawalpindi (gdzie znajduje się główna kwatera sił zbrojnych). Choć nieudany pucz doczekał się nawet osobnej monografii, w jego sprawie wciąż istnieje bardzo wiele znaków zapytania. Nie jest w szczególności jasne, czy przygotowania doń w ogóle wyszły poza fazę wstępnych rozmów oraz jaką rolę odegrały kontakty konspiratorów z podziemną Komunistyczną Partią Pakistanu, której obiecano legalizację ${ }^{14}$. Znane sa za to motywy spiskowców (pretensje do władz za „ugodowość" w kwestii kaszmirskiej oraz promowanie ich rywali w awansach) i strategia, jaka chcieli pozyskać sobie lud: zamierzali po prostu rozpisać wybory.

To ostatnie hasło musiało być dla Liaquata dzwonkiem alarmowym. Wobec rozsypki Ligi nie chciał on jednak przeprowadzać wyborów do parlamentu

${ }^{13}$ O Lidze Liaquat wyrażał się, że jest ona matką Pakistanu, a „tylko prawdziwa matka może się należycie zatroszczyć o swe potomstwo”. Więcej na temat jego podejścia do opozycji zob. A. McGrath, op. cit., s. 67-68 (rywalizujące ugrupowania określał m.in. „trującymi grzybami”).

${ }^{14}$ Partia ta była skądinąd grupą nawet nieraczkująca, świeżo wyodrębnioną ze swej indyjskiej bliźniaczki i ostro wewnętrznie skłóconą (także co do poparcia zamachu). Część badaczy twierdzi, że za ich pośrednictwem Akbar Khan zapewnił sobie wsparcie ZSRR, ale to akurat jest bardzo mało prawdopodobne, tak ze względu na mgławicowość samych kontaktów, jak i brak zainteresowania Moskwy Pakistanem. Zob. H. Zaheer, The Times and Trial of the Rawalpindi Conspiracy 1951. The First Coup Attempt in Pakistan, Karachi 1998, passim, zwł. s. 1-25, 161-302 (o roli komunistów: s. 204-233). 
krajowego przed odzyskaniem kontroli nad partią i pozbyciem się przynajmniej najbardziej buńczucznych oponentów. Bez konstytucji nie było zreszta jasne, na jakich zasadach je przeprowadzać. Szef państwa najchętniej darowałby też sobie wybory w prowincjach, ale w Pendżabie nie dało się ich już odwlekać: dwuletnie rządy gubernatorów wyczerpały cierpliwość mieszkańców oraz co ważniejsze, wszystkich frakcji tamtejszej Ligi. Odbyły się więc wreszcie w 1951 r., a Liaquat zaangażował z sukcesem cały swój autorytet, by do parlamentu dostali się ludzie wspieranego przezeń młodego działacza Miana Mumtaza Khana Daultany, nie nawaba Mamdotu. Rezultat odbijał te oczekiwania, choć słaby wynik Ligi w miastach stanowił ostrzeżenie na przyszłość. Było nim również ponad 4\% głosów zdobyte przez Jamaat-e-Islami (choć z racji ordynacji przypadł jej tylko jeden mandat), co zważywszy, że na wsi JI praktycznie nie istniała, wskazywało, że w miastach (nie tylko pendżabskich) integryści uzyskali szersze niż przedtem pole do działania.

Islam okazał się też główną osią debaty o przyjętej w pierwszym roku rządów Liaquata Rezolucji Celów (Objectives Resolution), pomyślanej jako preambuła przyszłej konstytucji; zawarte tam nawiązania do religii sprowokowały ostrą awanturę pomiędzy posłami hinduistycznymi i muzułmańskimi, oskarżającymi się wzajemnie o zdradę dziedzictwa Quaid-i-Azama. Kto miał rację, rozważam w innym tekście ${ }^{15}$, tu ograniczając się do refleksji, że Rezolucja na pewno nie była próbą rządowego appeasementu wobec ulemów, co inteligentniejsi z nich - jak mawlana Abul Ala Khan Maududi, przewodniczący JI - trafnie odczytywali. Przeciwnie, wyraźnie pokazywano tej grupie, gdzie jej miejsce; Liaquat nie krył, że to on sam i - szerzej - ekipa rządząca winni mieć monopol na określanie, co oznacza islamskość Pakistanu.

$\mathrm{Na}$ osobną wzmiankę zasługuje jeszcze jeden powód nacisku na rolę islamu: chęć uczynienia go sztandarem, pod którym będzie można zjednoczyć społeczeństwo zagrożone jakoby przez komunizm i materializm. Jak to ujął premier, Pakistańczycy winni „podążać za naukami Proroka, a nie Marksa, Stalina czy Churchilla” (sic!) ${ }^{16}$. Była już mowa o tym, że ów „komunizm” to w większości chimera - bardzo jednak przydatna rządowi w zwalczaniu opozycji czy obszarnikom $\mathrm{w}$ torpedowaniu reformy rolnej - w materializmie zaś same warstwy wyższe, posłów nie wyłączając, nurzały się bez względu na kwestie religijne. Ale też nie o zwalczenie konsumpcji tu chodziło. Islam, czego ze względów oczywistych nie można było powiedzieć wprost, miał stanowić remedium na zupełnie inny problem - erozje jedności i przywódczej roli samej Ligi oraz sprzeczne interesy w łonie społeczeństwa. Toteż nawet minister finansów Ghulam Muhammad, przy którym Liaquat mógł ujść za

\footnotetext{
15 T. Flasiński, op. cit.

${ }^{16}$ Cyt. za: A. Jalal, op. cit., s. 281. Nota bene już w wystapieniach Jinnaha pojawiało się przekonanie, że ideologia pakistańska reprezentuje via media pomiędzy „imperializmem” a „komunizmem”.
} 
religijnego gorliwca, publicznie wygłaszał namaszczone banały o „potrzebie czysto islamskiego fundamentu dla Pakistanu" ${ }^{17}$. W parlamencie elity władzy były wobec siebie szczersze i nikt nie tryskał oburzeniem, gdy poseł Ishtiaq Husain Qureshi zauważył w obecności Liaquata - odnosząc się jednak, trzeba dodać, do osobistej pobożności, nie do poglądów na ustrój - „nasza wizję moralności zasnuły chmury i generalnie mniemamy, że religia to tylko metoda eskapizmu"18.

W złośliwym, ale celnym ujęciu Ayeshy Jalal kwestie tego, jaką rolę winna odgrywać religia $\mathrm{w}$ państwie, stanowiły tak czy owak domenę niewielkiej liczebnie grupy ludzi z wyższych sfer, co „w sytuacji, w której większość społeczeństwa była niepiśmienna i żyła na wsi, kwalifikowało się jako «debata publiczna». A [...] miażdżąca większość Pakistańczyków po prostu żyła sobie jak zawsze". Ewentualne problemy czynione np. nieprzestrzegającym ramadanu nie miały zaś nic wspólnego z debatami ustawodawców, wszystko z nadgorliwością administracji lokalnej i czasem samozwańczych stróżów wiary ${ }^{19}$. Na razie spory o miejsce islamu w Rezolucji stwarzały inny kłopot - „przykrywały” dalece poważniejszą kwestię opieszałości parlamentu w pracach nad konstytucja. W półtora roku sklecono zaledwie preambułę, choć Jinnah za życia odgrażał się, że w tym czasie, a najpóźniej w dwa lata, wejdzie w życie cała ustawa zasadnicza. Dlaczego?

Z prostego powodu. Odziedziczona przez Pakistan po indyjskich wyborach 1946 r. konstytuanta ${ }^{20}$ była zupełnie niereprezentatywna, jako że - fenomen, który później już się nie powtórzył - Ligę poparła wtedy nawet rzesza muzułmanów mocno jej niechętnych, nie chcąc, by o ich przyszłości w kontekście rychłej dekolonizacji decydowała „hinduska” Partia Kongresu. Nie zmieniło tego drobne uzupełnienie składu parlamentu po podziale. Przyjęcie ustawy zasadniczej sprawiłoby, że wcześniej czy później niezbędne byłyby nowe wybory, co w obawie przed przegraną posłowie starali się maksymalnie odwlec. W odróżnieniu od Jinnaha popierał ich Liaquat, świadom, że najludniejszy w państwie Bengal Wschodni nie przepada za nim ani za Liga (będzie o tym mowa dalej): nie pomogło nawet powierzenie Bengalczykom obu dawnych stanowisk Quaid-i-Azama ${ }^{21}$. Prawda, od pośpiechu w tej sprawie odwodziła

${ }^{17}$ Cyt. za: F. Ispahani, Purifying the Land of the Pure. A History of Pakistan's Religious Minorities, New York 2017, s. 30.

${ }^{18}$ CAP, fourth session, 6 I 1949, s. 50.

19 Szerzej na ten temat zob. A. Jalal, op. cit., s. 277-294 (cytat: s. 281).

20 Zasiadło w niej 69 posłów wybranych na terenach, które później weszły w skład nowego państwa - zdecydowanie dominowało tu 44 deputowanych z Bengalu Wschodniego i 22 z Pendżabu, w 1948 r. dodano, chcąc stworzyć ułudę reprezentatywności, sześciu mohadżirów i czterech posłów z dawniej niezależnych władztw przyłączonych do Pakistanu w pierwszym roku jego istnienia. Zob. ibidem, s. 62 .

${ }^{21}$ Przewodniczącym parlamentu został Tamizuddin Khan, polityk drugiego garnituru partyjnego wywodzący się z ruchów chłopskich. 
również sytuacja państwa: w chaosie masowych migracji i w obliczu faktu, że na niektórych terenach kraju wyborów nie było w ogóle nigdy, trudno było myśleć o ich szybkim przeprowadzeniu (lepiej zorganizowane Indie zdobyły się na to dopiero w 1951, który był też rokiem pierwszego pakistańskiego spisu powszechnego).

Szanse na zmianę tego stanu rzeczy spadły w okolice zera, gdy Liaquat, któremu po latach starań udało się objąć przewodnictwo nad Liga i zaczaćc jej galwanizację - co wzmocniło też jego własną pozycję w państwie - został zamordowany na wiecu w Rawalpindi 16 X 1951 r. Tym samym naród pozostał bez powszechnie akceptowanego, przynajmniej wśród czołowych polityków, lidera. Wedle prawa śmierć premiera prowadziła automatycznie do rozwiązania rządu, nowy zaś powoływał wówczas gubernator generalny, czyli Khawaja Nazimuddin.

Nie jest jasne, dlaczego ten ostatni postapił inaczej: albo przeląkł się odpowiedzialności, albo dał się przekonać, że urząd premiera, formalnie podległy jego własnemu, waży w praktyce więcej - jak istotnie było za Liaquata ${ }^{22}$. Przejął więc stery osieroconego rządu, a szefem państwa - podobno za rada jednego z ministrów, Choudhury’ego Mohammada Alego - uczynił Ghulama Muhammada.

Ktokolwiek wpadł na ten pomysł, był on wręcz fatalny: odwrotna kombinacja mogłaby oszczędzić Pakistanowi wielu problemów. Nowy gubernator generalny nie wywodził się ze środowisk od dawna związanych z partia i badacze dość zgodnie przyjmują jego wyniesienie za punkt zwrotny, w którym realna władza przepłynęła od zawodowych polityków z Ligi do biurokratów. Z ruchem pakistańskim związał się w latach 1946-1947, porzucając świetnie prosperująca firmę samochodową: pomoc okazana wówczas Liaquatowi jako ministrowi finansów Indii Brytyjskich dała mu rychło takież stanowisko w rządzie Pakistanu. Ponieważ mało kto w Lidze znał się na gospodarce, pozycja Ghulama Muhammada była bardzo mocna - upatrywano w nim wręcz następcy Liaquata - co rychło przewróciło mu w głowie. Jego rozrośnięte ego i skłonność do uważania się za drugiego Jinnaha wspomniane zostały już w raportach amerykańskich z 1948 r. ${ }^{23}$ Sam Liaquat miał w końcu dość swego ministra i pod koniec rządów robił przymiarki, by się go pozbyć: ten ze swej strony otwarcie krytykował zwierzchnika na posiedzeniach gabinetu. Powierzenie człowiekowi o takich cechach i w dodatku sfrustrowanemu faktem, że od lat nie wdrażano w praktyce jego pomysłów na państwo (śmiałe

\footnotetext{
${ }^{22}$ Istotnym czynnikiem mogło być i to, że Liaquat zdążył wpoić Lidze, iż premier powinien jednocześnie być przewodniczącym partii, z sukcesją Nazimuddina również na tym stanowisku nie było więc kłopotu, choć ten w momencie śmierci poprzednika nawet do Ligi nie należał. L. Binder, Religion and Politics in Pakistan, Berkeley 1963, s. 245. Allen McGrath (op. cit., s. 79-80) relacjonuje różne wersje genezy nowego rozdania, w tym urban legend o tajnych naradach polityków nad szpitalnym łóżkiem konającego premiera.

${ }^{23}$ A. Jalal, op. cit., s. 108; A. McGrath, op. cit., s. 79-84.
} 
plany gospodarcze wymagały pieniędzy), urzędu w teorii najwyższego, a wedle obyczaju dekoracyjnego, stanowiło przepis na katastrofę.

Z kolei Nazimuddin o ile dobrze się czuł w roli doradcy Liaquata (dopóki tamten trzymał w rządzie jego krewnych i stronników), o tyle administratorem był niedołężnym, czego przed paru laty zasmakował już Bengal. Miał też zdumiewająco złe wyczucie nastrojów społecznych, co udowodnił w ciagu dwóch miesięcy od objęcia urzędu. Publiczną wypowiedzią w lutym 1952 r., iż jedynym językiem państwowym będzie urdu - Liaquat starał się kluczyć w tej sprawie - zantagonizował Dakkę; studencki protest, który się tam odbył 21 lutego mimo zakazu władz, stłumiono siła. 15 ofiar śmiertelnych, z marszu uznanych za męczenników, odebrało Lidze resztki legitymacji wśród bengalskiej klasy średniej - coraz głośniej przebąkującej o potrzebie autonomii, która zabezpieczy prawa miejscowego języka i położy kres dyskryminacji Bengalczyków przez „obcych” ${ }^{24}$. Wieś zraziła się do Ligi już wcześniej ze względu na rozdźwięk pomiędzy siermiężną rzeczywistością a ogromnymi obietnicami składanymi przez Ligę w kampanii wyborczej przed podziałem. Innymi powodami były niedoświadczenie i zwykła nieudolność rządu Nurula Amina, którego posunięcia mające na celu reformowanie wsi sabotowało w dodatku z przyczyn finansowych centrum ${ }^{25}$. Powszechna złość zamierzały zdyskontować nowe ugrupowania, wśród których na pierwszy plan wysuwała się Wszechpakistańska Muzułmańska Liga Awami (Ludowa), założona 23 VI 1949 r. a grupująca polityków związanych z Suhrawardym i drugim wybitnym trybunem ludowym regionu, mawlaną Ahmadem Bhashanim. Inaczej niż partii rządzacej nie brakowało jej zdolnych działaczy młodszego pokolenia, jak Sheikh Mujibur Rahman (powszechnie zwany Mujibem), przyszły prezydent Bangladeszu.

W tym kontekście można zrozumieć, że władze nie kwapiły się ani z nowymi wyborami w Pakistanie Wschodnim, ani nawet z wyborami uzupełniającymi w wypadku śmierci czy emigracji posłów, odkąd w maju 1949 r. ich kandydat poniósł w takich miażdżącą klęskę (do 1954 r. zawakowały w ten sposób 34 mandaty). Zwycięzcy nie pozwolono wówczas objać mandatu pod szytym grubymi nićmi zarzutem oszustw wyborczych. Zamiast tego parlament prowincji zwracał się regularnie do konstytuanty o roczna prolongatę swego istnienia, ta zaś, mając identyczny problem z legitymacja, chętnie udzielała zgody. Dodatkowo irytował Bengalczyków fakt, że wybory do parlamentów prowincjonalnych przeprowadzono w końcu również w Prowincji Północno-Zachodniej Granicznej i Sindzie.

${ }^{24}$ Zob. A.M.A. Muhith, State Language Movement in East Bengal, 1947-1956, Dhaka 2008, passim; A. Dil, A. Dil, Bengali Language Movement and the Creation of Bangladesh, Dhaka 2011, s. 137-200; Sheikh Mujibur Rahman, The Unfinished Memoirs, transl. F. Alam, Dhaka 2012, s. 197-203.

${ }_{25}$ Zob. A. Kamal, State against the Nation. The Decline of the Muslim League in Pre-independence Bangladesh, 1947-54, Dhaka 2009, passim. 
Gdy tylko rządowi centralnemu udało się metodą kija i marchewki przygasić płomień oporu w Bengalu Wschodnim, dla odmiany pogorszyła się sytuacja w Pendżabie. Coraz szersze kręgi zataczała tam agitacja przeciw ahmadystom - stworzonej pod koniec XIX w. przez tytułującego się prorokiem Ghulama Ahmada Mirzę islamskiej wspólnocie, która zdaniem poczesnej części muzułmanów sytuuje się poza obrębem tej religii. Jinnah, jak się zdaje, uważał inaczej, ale nigdy nie zdołano go skłonić publicznie do jasnej deklaracji w tej sprawie - Liga milcząco godziła się na przyjmowanie ahmadystów, z których Muhammad Zafrullah Khan został nawet bliskim współpracownikiem Jinnaha i pierwszym szefem MSZ Pakistanu, jednak $\mathrm{w}$ obawie przed zaognieniem atmosfery nie poruszano publicznie kwestii prawowierności wspólnoty ani za życia Quaid-i-Azama, ani po jego zgonie. Tymczasem na początku lat pięćdziesiątych przedpodziałowe jeszcze teorie spiskowe dotyczące tej grupy zyskały nowe życie; odwołanie Zafrullaha stało się jednym z postulatów coraz szerzej zakrojonej agitacji przeciw wspólnocie, obok zapisania we wciąż niegotowej konstytucji, że ahmadyści nie są muzułmanami (spełniło się to dopiero w 1974 r.). Żądania te, wsparte agitacja radykalnych ulemów, a za paliwo majace brak perspektyw zbiedniałych mieszkańców - poczynając od nieumiejących się odnaleźć na nowym miejscu mohadżirów - i ich zazdrość wobec lepiej sytuowanych (ahmadyści uchodzili za takowych), doprowadziły do serii rozruchów w Lahore, tlących się mniej lub bardziej intensywnie od poczatku $1952 \mathrm{r}$.

Panuje (i panowała) zgoda, że stanowcza akcja policyjna mogłaby szybko stłumić ruchawki, zabrakło jednak woli politycznej. Zorientowawszy się, iż krok taki przyniósłby tłumiącym spadek popularności, władze obu szczebli - prowincjonalny rząd Daultany i centralny Nazimuddina - przerzucały ten gorący kartofel między sobą. Daultana mógł się o tyle wymigać od odpowiedzialności, że w oczywisty sposób nie miał władzy, by spełnić którykolwiek z ww. postulatów ulemów, ci uderzyli więc do Nazimuddina. Ten zaś grał na zwłokę, łudząc się, że międzynarodowa konferencja ulemów mogłaby wyperswadować pakistańskim kolegom ich radykalne żądania ${ }^{26}$.

W końcu jednak cierpliwość Nazimuddina wyczerpała się, zwłaszcza że Daultana bezczelnie zbojkotował wezwanie do stolicy na naradę o przywróceniu

${ }^{26}$ Najlepsza monografia tematu: A.U. Qasmi, The Ahmadis and the Politics of Religious Exclusion in Pakistan, London-New York 2014, s. 35-118 (ustalenia Qasmiego sugeruja, że poczynania Daultany, w niejasny sposób powiązanego z kilkoma jadowicie antyahmadystowskimi periodykami, mogły być też elementem jakiejś szerszej politycznej intrygi); zob. też: Seyyed Vali Reza Nasr, The Vanguard of the Islamic Revolution. The Jama'at-i Islami of Pakistan, Berkeley 1994, s. 131-137; A. Jalal, op. cit., s. 151-154, 173-174; Report of the Court of Inquiry constituted under Punjab Act II of 1954, to enquire into the Punjab Disturbances of 1953, Lahore 1954, passim. Wersja elektroniczna raportu dostępna jest w kilku miejscach w Internecie, np. http://www.thepersecution.org/dl/report_1953.pdf (dostęp: 26 II 2018). 
porządku ${ }^{27}$. Gdy 27 lutego liderzy powołanego przez ulemów komitetu poprowadzili demonstrację pod siedzibę rządu i weszli do niej, chcąc wymusić na premierze odpowiedź, czekała tam na nich policja. Posłanie 721 demonstrantów (z ich szeregów atakowano policję kamieniami) za kraty uspokoiło sytuacje w Karaczi, za to rozpaliło ja w Lahore.

Rubikon został przekroczony 4 marca, gdy po kazaniu lokalnego radykała mawlany Niaziego tłum wychodzący z jednego z lahorskich meczetów wdał się w bójkę z policja, w której zginął funkcjonariusz. Dwa dni później gen. Azam Khan - dowódca 10 dywizji piechoty stacjonującej w Lahore - otrzymał od rządu centralnego rozkaz pacyfikacji miasta, co pociagnęło za soba, jak szacowali Brytyjczycy, 500-1000 zabitych i rannych ${ }^{28}$. Spowodowało to też rychły upadek Daultany, którego jednak najpierw zmuszono do publicznego wyrażenia poparcia dla interwencji wojska, tak by nie mógł się kreować na męczennika obalonego przez centrum.

Jeśli przyjrzeć się sprawie z dystansu (i znając materiały źródłowe), postawa Nazimuddina wcale nie wypada źle. Jego obawę przed posłaniem wojska na demonstrantów składa się zwykle na karb „pobożności”, ale równie dobrze mógł sobie zdać sprawę, jaki będzie to mieć skutek polityczny (po wydarzeniach z 21 II 1952 r.) i jaki rozlew krwi przyniesie (do czego armia jest tu zdolna, świetnie wiedział z czasów przed podziałem). Być może nieco zbyt mocno lawirował $\mathrm{w}$ rokowaniach $\mathrm{z}$ ulemami, ale nie był safanduła i potrafił podjąc decyzję o użyciu siły, gdy alternatywę stanowiłaby kapitulacja. Niemniej przegrał batalię wizerunkowo: dla nieprzychylnych integrystom kręgów - a były wśród nich wpływowe środowiska biurokratyczne i spora część elit, o armii i krajach Zachodu nie mówiąc - stał się wcieleniem nieudolności. Jak miałaby wyglądać udolność, sugerowała anglojęzyczna prasa, zachwycając się twardymi rządami Azama Khana w Lahore - a minister obrony Iskander Mirza, który ponoć odegrał istotna rolę w doprowadzeniu do interwencji, jawnie już głosił, iż „demokracja nie nadaje się dla Pendżabu”29. Więc może dla reszty kraju też nie?

Tymczasem Nazimuddin układając budżet, popełnił (raczej nieświadomie) kolejny błąd taktyczny. W stosunku do poprzedniego roku obcięto o 1/3 wydatki na armię - w sytuacji, gdy wypadki lahorskie umocniły jej mniemanie o sobie jako o jedynej odpowiedzialnej sile w kraju. Trudno go było jednak za to winić: wobec ciężkiej sytuacji należało zredukować też fundusze, np. na rozwój i import zboża, co nie przysporzyło rządowi miłości. Poza tym wojsko dostało już dodatkowe środki po stanie wojennym ${ }^{30}$. Próżno byłoby jednak

${ }^{27}$ NA, DO 35/5370, Gilbert Laithwaite [Wysoki Komisarz Wielkiej Brytanii w Pakistanie] do Commonwealth Relations Bureau (dalej: CRB), 4 III 1953, s. 10b.

${ }^{28}$ Ibidem, Laithwaite do Percivala Lieschinga (CRB), 11 III 1953, s. 38.

${ }^{29}$ Ibidem, Nota J.M.C. Jamesa [z Wysokiej Komisji Wielkiej Brytanii w Pakistanie, dalej: WK] z rozmowy z Mirzą i Azamem, 18 III 1953, s. 54, załącznik.

30 A. Jalal, op. cit., s. 178. Dlaczego nieświadomie? Budżet przegłosowano 14 marca, ledwo tydzień po pacyfikacji; o ile zachowane wówczas zostały typowe zasady obowiązujące 
perswadować to generałom, którzy uznali sprawę za kolejny kamień obrazy ze strony i tak pogardzanego rządu.

Miesiąc później, 17 kwietnia Ghulam Muhammad - który wcześniej czterokrotnie bez skutku próbował skłonić premiera do „rekonstrukcji” gabinetu - zaprosiwszy ministrów na rozmowę, zaproponował im dobrowolne złożenie stanowisk. Ponieważ nikt prócz Zafrullaha się nie zgodził, Nazimuddinowi zwyczajnie wręczono dymisję ${ }^{31}$. „Niezwyczajny rozwój sytuacji w Pakistanie ma rys iście gilbertowski” - dumał w Delhi zaskoczony indyjski premier Jawaharlal Nehru - „pałacowa polityka, pałacowe intrygi, tylko pałacu brak" 32 .

Głównym beneficjentem „spisku pałacowego” był Ghulam Muhammad, ale na niezależność w dużej mierze wybili się przy okazji wojskowi, którzy po raz pierwszy - choć pośrednio - wmieszali się w wielką politykę. Ich pewność siebie wzmagała wiedza, że prócz gubernatora generalnego sprzyja im Wielka Brytania ${ }^{33}$ i zwłaszcza USA - z którymi wbrew panislamskim mrzonkom Nazimuddina chcieli sojuszu ${ }^{34}$ - co częściowo objaśnia ich pomocna historykowi szczerość w rozmowach z przedstawicielami tych państw. Mirza miał wkrótce zasugerować Amerykanom, że w czasie próby sił pomiędzy piastunami dwóch głównych urzędów niewykluczona była interwencja wojska, gdyby sytuacja tego wymagała - cokolwiek to znaczyło ${ }^{35}$. Zaśs Ayub Khan, od 1950 r. dowódca armii, rychło pochwalił się konsulowi generalnemu USA

w parlamencie, posłowie otrzymali gotowy projekt do wglądu już pod koniec lutego. Stąd mylą się chyba badacze, którzy widzą w tych cięciach świadomy gest niechęci wobec wojskowych. Skądinąd wojsko i tak miało pochłonać $58,7 \%$ wydatków państwa, wobec $56,68 \%$ w poprzednim roku budżetowym. Wymowna tabela pt. „Wydatki na obronę 1947-59” zob. H.A. Rizvi, The Military and Politics in Pakistan 1947-86, Lahore 1987, s. 43-44.

${ }^{31}$ NA, PREM 11/1519, Laithwaite do CRB, 17 IV 1953, s. 69; ibidem, Laithwaite do CRB, „Pakistan: Dismissal of the Nazimuddin Ministry”, 8 V 1953, s. 10-12. Zob. też treść proklamacji szefa państwa przytaczaną w: M.A. Kundi, Ghulam Mohammad: His Life \& Work, „Journal of Political Studies” 2016, vol. XXIII, no. 2, s. 350-351 (korzystałem z wersji internetowej: http://pu.edu.pk/images/journal/pols/pdf-files/Mansoor\%20-\%2001_v23_2_16. pdf [dostęp: 26 II 2018]).

${ }^{32}$ Chodziło o Williama S. Gilberta, słynnego librecistę burleskowych operetek, np. Piratów $z$ Penzance. Nehru do Mountbattena, 19 IV 1953, w: Selected works of Jawaharlal Nehru, Second Series, vol. XXII, ed. R. Kumar, H.Y. Sharada Prasad, New Delhi 1998, s. 316-317 (korzystałem z wersji internetowej: http://nehruportal.nic.in/writings [dostęp: 26 II 2018]).

${ }^{33}$ Brytyjczycy w tym czasie zaczęli dość prymitywnie dzielić polityków pakistańskich na „promułłowskich” i resztę (w czym owa reszta, zwykle prozachodnia, co sił ich utwierdzała). Stąd radość dyplomatów: „Nowe rozdanie jest bardzo satysfakcjonujące, jeśli chodzi o wpływy mułłów, którzy utracili swych najsilniejszych sojuszników [w rządzie]”. NA, PREM 11/1519, Laithwaite do CRB, 18 IV 1953, s. 64.

${ }^{34}$ Wysoki komisarz w listach do Londynu nie krył nadziei, że nowy rząd „może się mniej palić do całego tego pomysłu z republika”, tzn. do porzucenia statusu dominium (całkowite wystapienie ze Wspólnoty Narodów nie było na razie, choć sugerowała to część ministrów Nazimuddina, realne). Ibidem, Laithwaite do CRB, 21 IV 1953, s. 51.

${ }^{35}$ A. Jalal, op. cit., s. 178. 
w Lahore, że „ciężko pracował, by osiagnaćc coś w tym stylu”, aż doczekał się dymisji premiera, „podarunku od Boga" ${ }^{6}$.

Abstrahując od roli Boga w tej sprawie, Jalal nie myli się chyba, twierdząc, że silny poparciem posłów Nazimuddin miałby pewne szanse w pakistańskiej grze o tron - gdyby nadawał się do niej pod względem charakteru i przebiegłości ${ }^{37}$. Tymczasem nie tylko nie przewidział ruchów rywala, ale po otrzymaniu dymisji ograniczył się do próby kontaktu z Elżbietą II, która chciał prosić o odwołanie Ghulama Muhammada. Gdy się to nie udało ${ }^{38}$, Nazimuddin spasował. Po dwóch dniach oświadczył publicznie, że choć jego dymisja była „niekonstytucyjna i nielegalna”, to „powaga sytuacji Pakistanu wymaga, bym nie czynił nic, co go osłabi" ${ }^{39}$, więc - może z obawy przed retorsjami - nie kiwną już palcem; przed upływem tygodnia ogłoszono oficjalnie, iż były premier przyją miesięczną pensję w wysokości 2 tys. rupii (w domyśle: $\mathrm{w}$ zamian za wycofanie się z polityki). Na osłodę zachował mandat parlamentarny, ale poważniejszej roli już nie odegrał.

Skoro sam usunięty nie myślał bronić własnych wpływów, tym bardziej nie palili się do tego jego stronnicy. Gdy więc Ghulam Muhammad wyznaczył nowego premiera, konstytuanta zatwierdziła go bez dyskusji, ministrowie

${ }^{36}$ Cyt. za: D. Kux, The United States and Pakistan, 1947-2000. Disenchanted Allies, Washington 2001, s. 54.

${ }^{37}$ Po zdymisjonowaniu szefa rządu Brytyjska Wspólnota Narodów nie mogła wszak zaprzeczyć, że gubernator generalny miał do tego prawo - podobnie jak w 1975 r., gdy do podobnego kroku posuną się australijski gubernator John Kerr. Prerogatywy gubernatora generalnego były wszak odbiciem prerogatyw monarchy brytyjskiego, a ten formalnie nadal „wyznacza” premiera Zjednoczonego Królestwa (argumentacja wyłożona szerzej w: NA, DO 35/5106, Laithwaite do CRB, 20 IV 1953, s. 18). Z drugiej strony uzus (ale nie formalnie spisana regułę) stanowiło powoływanie gubernatora generalnego przez głowę państwa brytyjskiego na podstawie rekomendacji rządu Pakistanu, choć nie było jasne, czy wycofanie takowej ma się kończyć dymisją szefa państwa; gdyby Nazimuddin uderzył pierwszy i zwrócił się do Elżbiety II o usunięcie Ghulama Muhammada, miałby za sobą nie najgorsze argumenty. Jak to ujął Londyn, „jeśliby urzędujący premier miał zwrócić się do królowej o dymisję gubernatora generalnego, Jej Wysokość przed przychyleniem się do tak niezwykłego żądania zapewne zwróciłaby się o pełną informację nt. okoliczności, które do tego doprowadziły", w tym o wersję samego odwoływanego (powołano się tu na casus Éamona de Valery z 1932 r.). „W wypadku nacisków w ostatecznym rozrachunku królowa musiałaby pójść za radą swych ministrów, nie mogą oni jednak oczekiwać od Jej Wysokości zgody na dymisję jej osobistego reprezentanta bez pełnej informacji o wszystkich aspektach sytuacji”. NA, PREM 11/1519, CRB do Laithwaite'a, 17 IV 1953, s. 66; zob. też: L. Binder, op. cit., s. 297, 306.

${ }^{38}$ Laithwaite nie przekazał telegramu Nazimuddina monarchini, wykręcając się, że „to sprawa między Pakistanem a pałacem [Buckingham], w która inny kraj Wspólnoty Narodów nie może ingerować" (NA, PREM 11/1519, Laithwaite do CRB, 17 IV 1953, s. 69), na polecenie szefa państwa uniemożliwiono zaś ekspremierowi wysłanie wiadomości inną drogą i odcięto mu telefon (ibidem, Laithwaite do CRB, 18 IV 1953, s. 61).

${ }^{39}$ Oświadczenie Nazimuddina za: ibidem, Laithwaite do CRB, 19 IV 1953, s. 57. Ekspremier zaczą się nawet wypierać, że próbował uzyskać u królowej odwołanie szefa państwa (dwa telegramy Laithwaite'a do CRB: NA, DO 35/5106, 19 IV 1953, s. 20-21). 
(nawet ci blisko związani z poprzednikiem) na ogół bezboleśnie przeszli do jego gabinetu, a Pakistańska Liga Muzułmańska powierzyła mu rychło przewodnictwo po Nazimuddinie - choć i ten szef rządu nie był dotąd jej członkiem ${ }^{40}$.

Beneficjentem owych zaszczytów stał się Muhammad Ali, nawab Bogry (zwany w skrócie Bogra dla odróżnienia od wspomnianego już Choudhury'ego Mohammada Alego), przed podziałem wieloletni minister w bengalskich gabinetach, a od 1948 r. ambasador w USA. Okazał się wcale sprawnym administratorem, ale za główna jego cechę chyba słusznie uznawano uległość wobec Ghulama Muhammada; dodatkowy atut stanowiły amerykańskie kontakty nowego premiera, których szef państwa chciał użyć do przeorientowania polityki zagranicznej na Waszyngton. Nie bez znaczenia było też bengalskie pochodzenie nominata; gubernator generalny chciał w ten sposób uniknąć wrażenia, że będąc Pendżabczykiem, pozbywa się z polityki reprezentantów wschodu (a wszyscy ministrowie stamtąd zostali akurat usunięci).

Inne gesty wobec Bengalczyków to uregulowanie statusu ich języka i korzystniejszy dla nich projekt konstytucji (o czym dalej), powołanie Akademii Bengalskiej w Dakce oraz przyzwolenie na wybory prowincjonalne. Rachuby Ghulama Muhammada, który wyraźnie liczył, że z wdzięczności za te koncesje (i za usunięcie Nazimuddina, sprawcy masakry z 21 II 1952 r.) Bengal Wschodni zagłosuje na Ligę, zawiodły jednak z kretesem. Mimo tytanicznej kampanii propagandowej, w którą włączono m.in. siostrę Jinnaha, w marcu 1954 r. Liga została zmiażdżona przy urnach przez szermujacy hasłem autonomii regionu Zjednoczony Front - koalicję bengalskich ugrupowań muzułmańskich z czołowym udziałem Ligi Awami ${ }^{41}$ - zdobywajacc 10 mandatów wobec jego $223^{42}$. Na mocy porozumień przedwyborczych premierem został Fazlul Huq z Partii Chłopskiej (Krishak Praja Party), niegdyś (1937-1943) pełniący tę funkcję w kolonialnym Bengalu.

Zarówno ze względu na centrolewicowy, reformatorski charakter tego gabinetu i jego bazy - część Frontu stanowiła Partia Demokratyczna, założona przez byłych komunistów - jak i na fakt, że składał się z polityków niechętnych ośrodkowi centralnemu oraz panoszeniu się Pendżabczyków na wschodzie, był on od początku władzom państwowym solą w oku. Te w efekcie odwołały się do intryg - nie można wykluczyć, że majowe rozruchy w jednej z przetwórni juty, w których padło ok. 500 ofiar, wybuchły z poduszczenia

\footnotetext{
40 A. Jalal, op. cit., s. 187; Sheikh Mujibur Rahman, op. cit., s. 246; L. Binder, op. cit., s. 309; Hamidul Huq Chowdhury, Memoirs. Autobiography, Dhaka 1989, s. 158; NA, PREM 11/1519, Laithwaite do CRB, 18 IV 1953, s. 60. Nie trzeba dodawać, że pieniądze na wojsko znów popłynęły szerokim strumieniem (Bogra: „zdecydowaliśmy, by nie podejmować w tej kwestii najmniejszego ryzyka"; cyt. za: H. Rizvi, op. cit., s. 43).

${ }^{41} \mathrm{~W}$ tym czasie porzuciła ona człon „Muzułmańska”, pragnąc zbudować trwalszy sojusz $\mathrm{z}$ hinduistami.

${ }^{42}$ Cały parlament liczył 309 miejsc, z tym że 72 zarezerwowane były dla hinduistów.
} 
Karaczi - równolegle strasząc zagranicę wizją licznych a agresywnych kohort spod znaku sierpa i młota. Rzekomo - co w dobie Dien Bien Phu mogło liczyć na posłuch - naginały one do swej woli gabinet Huqa, próbowały zburzyć wszelki ład w prowincji poprzez krwawy czyn rewolucyjny i tylko czekały, by z Bengalu Wschodniego spaść na Indie ${ }^{43}$.

Gwoździem do trumny Huqa okazał się błąd amerykańskiego korespondenta, który jego stwierdzenie o konieczności autonomii Bengalu Wschodniego zrozumiał jako żądanie niepodległości. Błyskawicznego dementi Karaczi nie miało ochoty słuchać - pretekst do zastapienia marchewki kijem był wprost wymarzony ${ }^{44}$. 30 maja gubernatorem prowincji mianowano Iskandra Mirzę i wprowadzono stan wojenny: w parę dni za kraty trafiło ponad 1300 działaczy Frontu i w ogóle opozycji (w tym 32 posłów). Sędziwy Huq znalazł się $\mathrm{w}$ areszcie domowym ${ }^{45}$; jedynie nieliczni - w tym Suhrawardy leczący się akurat w Zurychu - uniknęli celi, a Bengal ogarnęła polityczna apatia.

W tym miejscu wspomnieć należy o istotnym dokumencie, którego upublicznienie przypadło na ten okres. Jeszcze w $1953 \mathrm{r}$. parlament pendżabski powołał komisję śledcza, złożoną z Muhammada Munira, prezesa Sądu Najwyższego prowincji, i jego młodszego kolegi Malika Rustama Kayaniego, majacca za zadanie wyjaśnić przyczyny lahorskich zamieszek. Owocem ich pracy stał się potężny - jak się go obiegowo zwie - „raport Munira”, jedno z najlepiej znanych źródeł do historii ówczesnego Pakistanu.

Liczacy 387 stron dokument stanowił przede wszystkim smutny opis kolejnych faz zamieszek oraz prób zrzucania z siebie odpowiedzialności przez polityków - w trakcie rozruchów i po nich. Ale był też oczywiście gestem politycznym, i to trojakiego rodzaju. Po pierwsze, sędziowie wyraźnie mieli ochotę wpłynąć swym raportem na kształt ustroju pakistańskiego. Jak stwierdzali we wstępie, podczas przesłuchań ulemów i ahmadyckiego kalifa

${ }^{43}$ Sheikh Mujibur Rahman, op. cit., s. 269-272; zarząd fabryki jako instygatorów wskazywał wysoko postawiony pracownik firmy, do której przetwórnia należała: NA, DO 35/5336, G.D. Hampshire [z konsulatu Wielkiej Brytanii w Dakce] do Laithwaite'a, 27 III 1954, s. 26 (rozruchom poświęcona jest cała ta teczka). O ile w USA dawano bez zastrzeżeń wiarę owym alarmom, przytomniejsi reprezentanci Albionu (jak Laithwaite) zdawali sobie sprawę, że to absurd, nieliczni zaś komuniści bengalscy nie mieli interesu w sianiu anarchii. NA, DO 35/5377, „Pakistan: Review of Events, 1952-53”, 18 IV 1953, s. 1A, pkt 37.

${ }^{44}$ Zob. N. Kiran, The Federal Cabinet of Pakistan and Politics of East Bengal/Pakistan, 1947-1958, „IOSR Journal of Humanities and Social Science”, VIII 2016, vol. XXI, no. 8, s. 28-29 (korzystałem z wersji internetowej: http://iosrjournals.org/iosr-jhss/papers/Vol.\%20 21\%20Issue8/Version-9/D2108092334.pdf [dostęp: 26 II 2018]).

${ }^{45}$ H.F. Goodnow, The Civil Service of Pakistan. Bureaucracy in a new nation, London 1964, s. 104. Goodnow słusznie zauważa, że zarzuty były ewidentnie wyssane z palca, skoro ten sam Iskander Mirza rok później - już przejąwszy władzę w państwie i politycznie pojednawszy się z Huqiem - powierzył mu ministerstwo spraw wewnętrznych, odpowiedzialne m.in. za zwalczanie działalności antypaństwowej (ibidem, s. 105). 
dotknięto niemal każdej istotnej gałęzi ludzkiej wiedzy - religii [...] funkcji państwa i kościoła, suwerenności, demokracji i teokracji [...] owe zasadnicze dla śledztwa kwestie, które regularnie stawały tu na porządku dziennym w sposób bezpośredni, mają charakter tak głęboki i fundamentalny, że taki lub inny sposób reakcji na nie może stworzyć lub zniszczyć nowe Państwo Pakistańskie, całkowicie zmieniając przyszły bieg jego dziejów ${ }^{46}$.

Kayani i Munir podkreślając, że przesłuchiwani mawlanowie udzielali różnych odpowiedzi pytani, czym jest islam i kogo można uznać za muzułmanina, konstatowali, iż skoro islamu nie potrafią zgodnie i szczegółowo zdefiniować nawet jego uczeni znawcy, nie należy w ogóle odnosić doń porządku prawnego. Jako patrona podobnej wizji państwa przywołano tu Jinnaha, fałszując przy tym (być może nieświadomie) jego słowa ${ }^{47}$.

Wyrosła ze zrozumiałego sprzeciwu wobec pogromów chęć odcięcia ulemów od wpływu na państwo sprawiła, że autorzy raportu spróbowali nie tylko wykazać ich dość oczywistą winę w sprawie zamieszek, ale też całkowicie zgnębić wszystkich zwolenników ożenienia prawa i ustroju z ideami islamu. Jak pokazuje skądinąd sympatyzujący z sędziami Qasmi, przesłuchania mawlanów zostały dokonane i podsumowane tak, że musieli wypaść jako ludzie niepoważni i tępi. Po prostu prowadzono je pod tezę, iż islam znaczy dla każdego co innego, nie powinien więc mieć wpływu na życie publiczne; sprzyjało temu kompletne nieobycie ulemów ze światem specjalistycznego prawniczego idiolektu i ścisłych formuł jurysprudencji ${ }^{48}$. Munir i Kayani chcieli przez to przyczynić się do budowy państwa bardziej niż obecnie praworządnego i postępowego ${ }^{49}$; pułapka tego sposobu myślenia, której sędziowie nie widzieli lub widzieć nie chcieli, tkwiła w fakcie, że i praworządność, i nowoczesność (podobnie jak demokracja ${ }^{50}$ ) bywają definiowane nie mniej różnorodnie niż

${ }^{46}$ Report of the Court of Inquiry..., s. 6.

${ }^{47}$ Zob. ibidem, s. 187-232; S. Karim, op. cit., s. 29-41.

${ }^{48}$ Zob. A.U. Qasmi, op. cit., s. 140-145, 156-157.

${ }^{49} \mathrm{~W}$ swojej późniejszej o dwie dekady książce Islam in History Munir nie krył, że jego ideałem jest całkowity rozdział religii od państwa, „co nie oznacza, że jego obywatele i prawodawcy nie wierzą w Boga; oznacza tylko, że organizuja swoje świeckie, przyziemne sprawy bez odwołań do nadnaturalnych czy niebiańskich sił", bowiem - jego zdaniem - tylko świeckość umożliwia państwu rozwój. Cyt. za: Syed Adnan Hussain, Negotiating Pakistan. A Genealogy of a Post-colonial Islamic State, [niepublikowana praca doktorska obroniona na University of Toronto], 2015 (korzystałem z wersji internetowej: https://tspace.library. utoronto.ca/bitstream/1807/70066/3/Hussain_Syed_Adnan_201506_PhD_thesis.pdf [dostęp: 26 II 2018]), s. 136-137.

${ }^{50}$ Abstrahując od faktu, że przeciwstawianie „państwa islamskiego” ideałom demokracji było w ustach Munira okrutnym żartem, raport pomijał fakt, że ustroje stawiane czytelnikom za przykład państw Zachodu nakładały na nieskrępowaną wolę ludu nie mniej ciasny kantar niż „islamskie” zapisy prawne proponowane przez Liaquata i jego bezpośrednich sukcesorów - tyle że mniej się z tym obnosiły. Zob. np.: J.W. Müller, Przeciw demokracji. Idee polityczne XX wieku w Europie, tłum. J. Majmurek, Warszawa 2016. 
islam, a udowodnić miały to wkrótce poczynania samego Munira. W ostatecznym rozrachunku istotniejsze od pojęć jest zawsze to, kto ma władzę ich definiowania: Zafrullah w polemice $\mathrm{z}$ hinduistycznymi protestami przeciw odwołaniom do islamu w Rezolucji Celów zauważał ongi słusznie, że skoro demokracją zwie się tak USA, jak ZSRR, samo umieszczenie tego wyrazu $\mathrm{w}$ konstytucji zamiast fragmentów o religii nic by nie zmieniło ${ }^{51}$. W tym sensie raport był także głosem w debacie, komu oddać taką władzę - poza samym Munirem, który już przyznał ją sobie w stosunku do pojęcia islamu, a w przyszłości miał tę listę znacznie poszerzyć.

I rzeczywiście - to po drugie - nakreślono tu implicite kierunek pożądanej ewolucji ustroju. „Coś, co zwą ludzkim sumieniem, sugeruje nam zbadać, czy na obecnym stopniu rozwoju politycznego administracyjny problem utrzymania prawa i porządku nie może zostać rozdzielony od swego demokratycznego towarzysza zwanego Rządem, tak okrutnie gnębionego przez polityczne koszmary. Lecz jeśli demokracja znaczy, że prawo i porządek zależeć maja od celów politycznych - wtedy Allah wie najlepiej, my zaś kończymy raport" - brzmiała końcowa refleksja sformułowana, jak zauważył Syed Adnan Hussain, w sposób przywodzacy na myśl fatwę ${ }^{52}$. A nieco wcześniej, podnosząc bierność służb porządkowych i organów władzy w obliczu mordów i jątrzących mów, cytowano jeden z gazali Dżalaluddina Rumiego: „Marzy mi się Lew Boży i Rostam syna Zala" ${ }^{53}$. Nazwiska Ghulama Muhammada czy Iskandra Mirzy w raporcie w ogóle nie padały, a jednak w kontekście tych stwierdzeń i pogardliwie paternalistycznego tonu, w jakim Munir wyrażał się o kunktatorstwie odwołanego Nazimuddina (w tej sytuacji to zreszta również gest polityczny), trudno było mieć wattpliwości, gdzie szukać następców dawnych witeziów. Kandydatom wyraźnie stawiano dwa wymogi - świeckość i siłę, a pierwszy z nich przekreślał z góry kontynuatorów linii Liaquata.

Podpiera tę konkluzję - to po trzecie - analiza treści, których w raporcie nie ma. Nie padło np. pytanie, czy środki zastosowane przez wojsko nie były nadmierne - dość istotne, skoro w pacyfikacji zginęło znacznie więcej ludzi niż w samych zamieszkach. Brytyjczykom trzeba przyznać, że w ostatnich latach rządów kolonialnych, choć niekiedy starali się uniknąć szczerej odpowiedzi na to pytanie, po rozruchach zawsze je stawiano. Argument, że nie mieściło się to $\mathrm{w}$ mandacie Munira i Kayaniego, należy odrzucić - nie mieli oni problemu, by zawrzeć w tekście osobny podrozdział poświęcony obronie

${ }^{51}$ CAP, fifth session, 12 III 1949, s. 68.

52 Syed Adnan Hussain, op. cit., s. 145.

${ }^{53}$ Pełen dwuwiersz brzmi „Obmierźli mi ci niemrawi towarzysze drogi / Marzy mi się Lew Boży i Rostam syn Zala”. Autor dziękuje Ivonnie Nowickiej za przełożenie tej frazy z perskiego i Saleenie Karim za konsultacje. Wzmianka o lwie dotyczy zapewne kalifa Alego, zwanego z racji waleczności „Lwem Bożym” (choć język wskazuje, że Rumi chciał tu położyć nacisk na cnotę męstwa, nie konkretną osobę). Z kolei Rostam - postać fikcyjna - to bohater perskiego eposu Ferdousiego Szahname (Księga Królewska), pogromca m.in. smoka. 
wojska przed zarzutem niedostatecznej współpracy z administracją cywilna, choć to również nie wchodziło w skład postawionych im celów. Uważali raczej, że liczba kul wystrzelonych w uczestników rozruchów to rzecz mało istotna wobec faktu, iż „praworządni obywatele odetchnęli z ulga" ${ }^{54}$. Podobnie jak fakt, że wojsko władało miastem ponad dwa miesiące po stłumieniu zamieszek, m.in. zapewniając sobie PR kampania sprzątania „Czystsze Lahore” ${ }^{55}$.

O tym, że sędziom nie szło tu o obiektywizm, lecz o zasugerowanie czytelnikowi dychotomii „strzegące porządku i zdecydowane wojsko - zagubieni, egocentryczni, tchórzliwi politycy", najlepiej świadczy podrozdział o wydarzeniach bezpośrednio poprzedzających stan wojenny. Opisując pertraktacje Nazimuddina z ulemami i pokrętne poczynania Daultany, kończy się on zdaniem: „Wojsko nie mogło czekać dłużej i przejęło kontrolę"56. Niewtajemniczonym mogło się wydać, że to nie rząd nakazał interwencję - bo tej informacji w tekście w ogóle brak - lecz sami dowódcy wojskowi, wbrew zagubionym cywilom, postanowili ratować Lahore.

Same w sobie cytowane tu stwierdzenia nie uprawniałyby może do tak daleko idących wniosków. Właściwym jednak kontekstem jest tu dla nich nie reszta raportu, lecz dalsze działania obu autorów. I o ile kariera Kayaniego sugeruje, że składał pod tymi zdaniami podpis po prostu z tęsknoty za nieco sprawniejszym rządem, konsekwentnie egzekwującym przepisy, inaczej rzecz miała się z Munirem.

Aby wyjaśnić kontekst polityczny, w jakim zyskał on pole do działania, trzeba krótko zreferować, co w tym czasie robiła ledwo obecna w toku powyższych wywodów konstytuanta. Wraz z promulgowaniem Rezolucji Celów powołała ona do przygotowania ustawy zasadniczej Komitet Zasad Podstawowych (Basic Principles Committee - BPC), a ten z kolei szereg podkomitetów mających zająć się poszczególnymi aspektami tej pracy. Jej efekty poznano dopiero po 18 miesiącach i nie był to jeszcze gotowy projekt, lecz jedynie tzw. Raport Przejściowy (Interim Report). Prezentacja jego ustaleń we wrześniu 1950 r. wzbudziła błyskawiczny i wściekły opór Bengalu Wschodniego; szło przede wszystkim o nieszczęsne urdu, które zalecano uczynić językiem państwowym, ale uważano też powszechnie, że zapisy Raportu dają rządowi centralnemu zbyt wielką władzę nad prowincjami. Zważywszy też na narzekania środowisk prawniczych na niejasność niektórych artykułów, Liaquat

\footnotetext{
${ }^{54}$ Report of the Court of Inquiry..., s. 357.

${ }_{55}$ A. McGrath, op. cit., s. 191; H. Rizvi, op. cit., s. 60-61.

${ }^{56}$ Report of the Court of Inquiry..., s. 235. Zdanie to, wraz z mylnymi informacjami zawartymi w jednym z wczesnych brytyjskich raportów, w rzeczy samej stało się pożywką dla pokutującej w historiografii teorii, jakoby o użyciu sił zbrojnych zadecydował na własna rękę gen. Azam Khan, nie mogąc się doczekać wytycznych (np.: A. Jalal, op. cit., s. 177). Jest ona całkowicie sprzeczna $\mathrm{z}$ faktami, rozbieżności istnieją natomiast co do roli Iskandra Mirzy w skłonieniu rządu do interwencji - temat ten wykracza jednak poza zakres niniejszego tekstu.
} 
poczuł się zmuszony schować całość do kieszeni i nakazać BPC stworzenie nowej wersji z uwzględnieniem napływających uwag.

Zadanie to zajęło Komitetowi 27 miesięcy (!), toteż nowy projekt zaprezentowano już po śmierci Liaquata, 22 XII 1952 r. Różnił się on od poprzedniego głównie ogromnymi prerogatywami głowy państwa ${ }^{57}$ oraz wzmocnieniem pozycji Pakistanu Wschodniego, w tym brakiem wzmianek o urdu (co w praktyce mogło - acz nie musiało - oznaczać uznanie oficjalnego statusu języka bengalskiego) $)^{58}$.

Nie to jednak wzbudziło największe kontrowersje, lecz przewidziana w projekcie pięcioosobowa „rada ulemów”, też nominowana przez głowę państwa. Miała ona oceniać wzbudzające watpliwości projekty ustaw (poza tymi, które dotyczyły gospodarki) pod kątem ich zgodności z zasadami islamu; jednogłośna opinia negatywna odsyłałaby nowe prawo z powrotem do parlamentu, w przeciwnym razie głowa państwa decydowała sama, czy je podpisać ${ }^{59}$. Mało tego, analogiczne rady powstać miały na szczeblu prowincji, z gubernatorem jako tworzacym je organem.

Efektem pomysłu była furia większości pakistańskich warstw wyższych, której ulemowie kojarzyli się z islamem nie tylko antynowoczesnym, ale też próbującym wtrącać się w życie prywatne, w tym ich własne. O ironio, sami ulemowie protestowali równie mocno - głównym powodem wydaje się obawa, że obsadziwszy radę dyspozycyjnymi wobec siebie uczonymi, rząd zacznie następnie traktować ich jako główne autorytety w sprawach religii w ogóle, przed którymi wszyscy pozostali winni się kornie chylić. Zważywszy na kształt zapisów, mieli rację: szło w nich o zneutralizowanie radykałów i ukrycie przed nimi tego celu drobnym ustępstwem symbolicznym, nie o islamizację. Pozbawiona rzecz jasna szans propozycja Maududiego, by pięciu sędziom Sądu Najwyższego dodać pięciu ulemów i zapomnieć o pomyśle osobnej rady,

${ }^{57} \mathrm{~W}$ jego gestii było zawieranie traktatów międzypaństwowych, wypowiadanie wojen, zwoływanie, odraczanie obrad i wreszcie rozwiąywanie parlamentu, a wszelkie ustawy przed wejściem w życie musiały być przezeń podpisane. Wybierał też premiera - który jednak musiał być posłem albo po obiorze zdobyć taki mandat w ciagu pół roku - i wyznaczał mu ministrów (choć odpowiadali oni przed izbą poselska). Wszyscy oni zresztą i tak mieli wobec szefa państwa głównie głos doradczy. Dalszych badań domaga się kwestia, dlaczego projekt - inaczej niż poprzedni - dawał szefowi państwa tak ogromną władzę, zwłaszcza że po obiorze parlament nie miałby nad nim kontroli - by mógł go zdjąć z urzędu, on sam musiałby najpierw zwołać obrady tego ciała. Znana mi literatura przedmiotu tematu nie podejmuje; jedynym wyjaśnieniem, jakie przychodzi mi na myśl, jest chęć umieszczenia na tym stanowisku kogoś sterowalnego - Nazimuddin? Tamizuddin? - kto zapewniłby kolegom z ław poselskich synekury mogące im zastapić często nieuniknioną przegraną w wyborach do nowego parlamentu i kogo ten ostatni nie mógłby obalić. Byłoby to oczywiście działanie nader krótkowzroczne, ale chyba wyobrażalne. Teza ta bez watpienia wymaga jednak źródłowej weryfikacji.

${ }^{58}$ Tekst projektu: CAP, twelfth session, 22 XII 1952, s. 80-160.

${ }^{59}$ Ibidem, s. 86-88. 
dobrze oddawała rozterki mawlanów. Spory wzbudziła też kwestia Bengalu/ Pakistanu Wschodniego, bo dla polityków (i mieszkańców) Pendżabu dominacja wschodu w państwie, choć zgodna z pryncypiami demokracji, była nieakceptowalna. Z kolei reszta zachodnich prowincji bała się zmajoryzowania przez Pendżab właśnie ${ }^{60}$.

Nowy projekt BPC nigdy nie został szerzej przedyskutowany w parlamencie - miało to nastapić $\mathrm{w}$ styczniu, ale pod naciskiem różnych ugrupowań politycznych odłożono sprawę, potem zaś cała uwagę władz skupił kryzys lahorski. Byka za rogi chwycił dopiero Bogra, proponując w ciagu kilkunastu miesięcy po nominacji cały szereg sensownych poprawek. Zgodność ustaw $\mathrm{z}$ islamem (nie można się było z tego wycofać bez polemiki z fundamentami idei pakistańskiej) mieli teraz badać nie ulemowie, ale Sąd Najwyższy ${ }^{61}$; bengalski razem z urdu oficjalnie uznano za języki państwowe (wydaje się, że prócz doraźnych celów politycznych władze pragmatycznie potraktowały dyskryminację bengalszczyzny jako znacznie głębiej dzielącą kraj niż brak wspólnego języka); formalna sankcję otrzymała nieoficjalna zasada, że szefowi państwa z Pakistanu Zachodniego musi towarzyszyć szef rządu ze Wschodniego lub odwrotnie. Problem z kompozycją parlamentu zamknięto zaś tzw. formuła Bogry ${ }^{62}$.

Jak na warunki Pakistanu wypracowanie tu i w innych kwestiach zasad zdolnych zadowolić większość było osiagnięciem niebywałym (co osobliwe, nie wzbudziło specjalnych kontrowersji utrzymanie w projekcie ogromnych uprawnień prezydenta). Choć więc protestowali Huq i inni zwolennicy autonomii Bengalu Wschodniego, choć miesiącami kłócono się o kwestie administracyjne $^{63}$, a integrystów rozjuszył fakt, że nie dostali nic w zamian za skasowana „radę ulemów” - Maududi grzmiał, że równie dobrze spodziewać się można wyrośnięcia mango na drzewie pomarańczy, jak i wprowadzenia prawdziwie islamskich praw przez modernistyczne warstwy rządzące ${ }^{64}-\mathrm{w}$ będącej

${ }^{60}$ Szerzej na temat kontrowersji związanych z projektem zob. Riaz Ahmad, Pakistan's First Constituent Assembly's Efforts for the Making of Constitution, 1947-1954, „Pakistan Journal of History \& Culture" 2002, vol. XXIII, no. 1, s. 14-16.

${ }^{61}$ Co oznaczało ni mniej, ni więcej, tylko że ostatecznym suwerenem w sprawach wiary będzie ciało całkowicie świeckie. Więcej na ten temat zob. L. Binder, op. cit., s. 341.

${ }^{62}$ Do jednej z izb parlamentu wysyłać miała 10 delegatów każda prowincja, w drugiej zaś, wyłanianej w wyborach powszechnych, miejsca rozdysponowano stosownie do liczby ludności - Bengal Wschodni otrzymał w niej np. 165 z 300 posłów. Istotne kwestie dotyczące państwa miały być przedmiotem decyzji łączonych obu izb, przy czym większość oznaczać miała, że co najmniej 30\% reprezentantów tak wschodu, jak zachodu poprze daną propozycję.

${ }^{63}$ Chodziło o pomysł tzw. One Unit, połączenia zachodnich prowincji w jedna - promowany przez Pendżabczyków dla zrównoważenia wpływów Bengalu Wschodniego i znienawidzony przez wszystkich innych.

${ }^{64}$ Cyt. za: Fakhr-ul-Islam, M. Iqbal, Islamizing the Constitution of Pakistan: The Role of Maulana Maudoodi, „Al-Idah”, XII 2013, no. 27, s. 67 (korzystałem z wersji internetowej: http://www.szic.pk/journal [dostęp: 26 II 2018]). Bogra chciał początkowo w ogóle wyciąc 
przedtem przedmiotem zajadłych sporów materii przyszło uspokojenie, i to znaczne. Wciąż opornych hinduistów, po staremu sarkających przeciw „wykańczaniu mniejszości” Rezolucją Celów ${ }^{65}$, wytłumienie różnic w gronie posłów muzułmańskich pozwalało zwyczajnie przegłosować. Rozpatrzywszy punkt po punkcie zapisy ustawy zasadniczej, można było przedstawić ją publicznie - nieoficjalnie zaplanowano to na 27 października, zaś głosowanie nad jej przyjęciem - na połowę grudnia. 2 października Bogra zapowiedział, że konstytucja zostanie przyjęta przed 25 grudnia - rocznicą urodzin Jinnaha, w Pakistanie stanowiąca święto państwowe.

Choć pośpiech tych prac był znaczny, dla opinii publicznej konstytuanta stanowiła już synonim czegoś odwrotnego - monstrualnej gnuśności. Trudno się temu dziwić: jak wyliczono, zbierała się ona średnio na $16 \mathrm{dni} \mathrm{w}$ roku, a i wtedy absencja wynosiła na ogół ok. $1 / 3$ składu izby ${ }^{66}$. W dodatku ta pierwsza liczba byłaby jeszcze niższa, gdyby wyłączyć z analizy okres po dymisji Nazimuddina. Ewidentnie dopiero wtedy posłowie zakasali rękawy - albo w obawie, że po usunięciu szefa rządu mogą być następni, albo dlatego, że ze sceny zniknęli dwaj premierzy, którym szybkie promulgowanie konstytucji wcale nie było na rękę. Właśnie ten ostatni fakt wydaje się wyjaśniać opieszałość parlamentu: po spisie powszechnym roku 1951, który dał wreszcie niezbędne do ustalenia wielkości adekwatnej reprezentacji dane na temat zaludnienia kraju, mogło już chodzić tylko o to, że konstytucja oznaczałaby rychłe wybory. Te zaś zapewne odsunęłyby od władzy większość i posłów, i rządu.

Ponieważ Liaquata $\mathrm{z}$ racji śmierci, a Nazimuddina $\mathrm{z}$ powodu dymisji nie było już w wielkiej polityce, całe odium za potworną zwłokę w stabilizacji ustroju spadło na nie całkiem tego świadomy parlament. W rzeczy samej pierwszy krok Suhrawardego i Huqa po wygranych wyborach w Bengalu Wschodnim stanowił (zignorowany oczywiście) apel do posłów konstytuanty z tej prowincji, by ustapili, gdyż nie reprezentują już nikogo.

Tymczasem trzy miesiace po obaleniu rządu Huqa, gdy debaty nad nowym projektem konstytucji weszły w fazę finalna, stan zdrowia Ghulama Muhammada gwałtownie się pogorszył. Kiła, na która cierpiał od lat, zaatakowała układ nerwowy: szef państwa doznał paraliżu kończyn i był odtąd skazany

„islamskie” zapisy z ustawy zasadniczej - za czym bez watpienia stał jego pryncypał - ale później zmienił zdanie. Przyczyna wymaga dalszych badań, na pewno jednak myli się Jalal wiążąca tę woltę z walką Ligi o głosy Bengalczyków - kolejny projekt, z pozostawionymi spornymi fragmentami, przedstawiono, gdy walkę ową sromotnie już przegrano. A. Jalal, op. cit., s. 184-185. Mimo wszystko trudno orzec, czemu - jak zaświadcza Binder, prowadzący wówczas badania na ten temat na miejscu - liczni Pakistańczycy postrzegali ów projekt jako „wielkie zwycięstwo religiantów”. L. Binder, op. cit., s. VII.

${ }^{65}$ CAP, sixteenth session, 24 VIII 1954, s. 289. Cytowane słowa wypowiedział poseł Sris Chandra Chattopadhyaya.

${ }^{66}$ Dane za: Syed Adnan Hussain, op. cit., s. 147. 
na wózek inwalidzki, a jego mowa stała się tak niezrozumiała, że większości gości musiała ją tłumaczyć pielęgniarka ${ }^{67}$.

Konstytuanta dostrzegła w tym niepowtarzalna szansę na umocnienie swej pozycji (od początku 1954 r. regularnie okrawała uprawnienia szefa państwa, ale w drobniejszych sprawach). A może po prostu chciała wyprzedzić ruchy przeciwnika. Do radykalnych działań pchnęła ją ponoć nieoficjalna informacja, że na biurku Ghulama Muhammada leżą nie mniej niż 22 wnioski o wszczęcie wobec posłów - głównie bengalskich - i innych niechętnych mu polityków postępowania na mocy PRODA ${ }^{68}$.

20 września z parlamentarnej „zamrażarki” znienacka wydobyto wniosek z 1951 r. o uchylenie PRODA i nagle okazało się, że nikt nie jest skłonny bronić przyjętego ongiś miażdżącą większością głosów prawa. Jego dawni zwolennicy tłumaczyli, że zgrzeszyli optymizmem i wiarą w powściagliwość Liaquata, a „czyny dokonane na podstawie ustawy były gorsze niż te, które ustawa miała karać"69. Propozycja (niezmieniajacca jednak statusu już skazanych czy będących obiektem postępowań ${ }^{70}$ ) przeszła więc z łatwościa, podobnie jak następnego dnia zmiana - oficjalnie w ramach przygotowań do wprowadzenia analogicznego systemu w konstytucji - zapisów Government of India Act. Odtąd członków rządu można było powoływać jedynie spośród parlamentarzystów, chyba że nominat w ciagu pół roku od objęcia stanowiska zdobyłby mandat poselski. Co więcej, wotum nieufności wobec choćby jednego ministra automatycznie pociagało za sobą dymisję całego gabinetu ${ }^{71}$.

Obawa, że w ostatniej chwili Ghulam Muhammad mógłby pokrzyżować te plany, była ewidentna: nowe prawo przyjęto, gdy wybrał się on w podróż na północ państwa, a Bogra, Mirza i Ayub mieli następnego dnia wyruszyć do Waszyngtonu ${ }^{72}$. Projekt poprawek rozdano ponoć posłom, wedle różnych

${ }^{67}$ Hamidul Huq Chowdhury, op. cit., s. 159; M. Ayub Khan, Friends not Masters. A Political Autobiography, London 1967, s. 62. Jak zły był stan szefa państwa, świadczy relacja z maja 1955 r. o „wręcz niebywałej poprawie” wyrażającej się tym, że chory „siedzi i czyta”. NA, PREM 11/964, Laithwaite do CRB, 5 V 1955, s. 24.

${ }^{68}$ L. Binder, op. cit., s. 353-357. Informację tę - bez dokładnej liczby, za to z szeregiem nazwisk - potwierdzaja źródła brytyjskie oraz amerykańskie, dodając, że część wniosków inspirował Iskander Mirza. NA, Waszyngton, [John] Emmerson [chargé d'affaires ambasady USA w Karaczi] do sekretarza stanu, 25 IX 1954. Ten i kolejne dokumenty z archiwów amerykańskich cytowane sa za cyfrowymi kopiami z internetowej bazy Paula Wolfa (http:// web.archive.org/web/20120314192556/http://www.icdc.com/ paulwolf/pakistan/pakistan. htm). Dalej oznaczam ich pochodzenie skrótem NAPW.

${ }^{69}$ CAP, sixteenth session, 20 IX 1954, s. 420, cała debata: s. 419-451.

70 Tym wkrótce przywrócił prawo do piastowania urzędów szef państwa, próbując ich pozyskać przeciw konstytuancie. NA, DO 35/5114, Dekret Ghulama Muhammada, 20 X 1954, s. 5. Skądinąd chciał też w ten sposób pokazać, że może wyroki skracać...

${ }^{71}$ CAP, sixteenth session, 21 września 1954, s. 499-502.

${ }^{72}$ Nota bene przesilenie w Pakistanie mogło przy okazji przekreślić plany ścisłego sojuszu z USA, ukochanego dziecka „grupy trzymającej władzę”, którego szczegóły negocjować miała wspomniana wyżej trójka; spora część posłów (i społeczeństwa) za Stanami nie 
wersji, z ledwie dziennym lub parogodzinnym wyprzedzeniem i promulgowano je bez większości pendżabskich parlamentarzystów - najbliższych Ghulamowi Muhammadowi - którzy zbojkotowali sesję ${ }^{73}$. Domysły zaczynaja się, gdy idzie o polityczne tło całej sprawy. Kilka różnych źródeł zgodnie podaje, że posłów wspierał premier, który w stanie zdrowia pryncypała dostrzegł szansę uwolnienia się od jego uciążliwej kurateli, a przedtem próbował bezskutecznie odwieść go od nadużywania PRODA. Sam Bogra twierdził, iż posłowie działali w porozumieniu z nim, ale równie dobrze mógł robić dobrą minę do złej gry $^{74}$. Ambasada USA najpierw uważała, że szefa rządu zastraszono groźba odwołania, potem wiązała jego motywy z oburzeniem na politykę pałki, która z błogosławieństwem szefa państwa Iskander Mirza wprowadzał w Bengalu Wschodnim $^{75}$. Jalal, nie wypowiadajac się o motywach Bogry w tej sprawie, sugeruje je w innym miejscu swej książki, malując obraz człowieka, którego armia i biurokracja bez żenady używały jako „zderzaka”, obarczając go odpowiedzialnościa m.in. za fiasko rokowań z Indiami w sprawie Kaszmiru ${ }^{76}$.

Obraz ten mącą nie tylko rozmaite dziwne plotki zanotowane w źródłach ${ }^{77}$, lecz i dobrze zazwyczaj zorientowany w ,pałacowych” intrygach doradca Ghulama Muhammada, Ivor Jennings. W późniejszym okresie podał on, iż wraz z przyjęciem nowej konstytucji planowano wotum nieufności wobec obecnego rządu, na szefa kolejnego szykując Abdura Raba Nishtara ${ }^{78}$. Jeśli jest to prawda, sugeruje, że posłowie zamierzali ostatecznie ograć i Bogrę, bądź co bądź outsidera w tym gronie.

O ile takie były ich zamiary, Bogra pozostawał w nieświadomości: jeszcze 23 października - schwytany przez reporterów na stopniach samolotu, którym wracał z USA - powtórzył zapowiedź przyjęcia ustawy zasadniczej w grudniu. Atoli w ciagu kilkunastu godzin nadzieje i jego, i parlamentarzystów obróciły się wniwecz: „Zważywszy na polityczny kryzys, przed którym stanął kraj,

przepadała, a sam projekt miała za neokolonialny (zob. „Dawn”, 24 IX 1954). Nie dziwi zatem, że sytuacja wzbudziła popłoch w kręgach wojskowych: Iskander Mirza miał na wieść o niej „osłupieć” i „wyprowadzony z równowagi ćmić jednego papierosa po drugim”. NAPW, [Emmerson?] do [Horace'a] Hildretha [ambasadora USA w Pakistanie], 25 IX 1954. Strach był jednak, oczywiście, obopólny, bo posłowie nie mogli wykluczyć, że wojsko użyje siły. O zabiegach armii dotyczących ww. sojuszu zob. D. Kux, op. cit., s. 44-74; A. Jalal, op. cit., s. 170-172, 175-177, 181-183, 186-188.

${ }^{73}$ NA, DO 35/5111, Laithwaite do CRB, 22 IX 1954, s. 5.

${ }^{74}$ Ibidem; NAPW, nota z rozmowy Hildretha z Bogra, 13 X 1954.

75 NAPW, Emmerson do Departamentu Stanu, 25 IX 1954.

${ }^{76}$ A. Jalal, op. cit., s. 182.

${ }_{77}$ Po przeprowadzeniu swych zamiarów przez konstytuantę Londyn informowano m.in., że zirytowany okrojeniem jego kompetencji Ghulam Muhammad chciał złożyć urząd, ale odwiódł go od tego... Bogra. NA, DO 35/5111, Dalton Murray (WK) do A.F. Morleya (CRB), 24 IX 1954, s. 7.

${ }^{78}$ Constitution-Maker. Selected Writings of Sir Ivor Jennings, ed. H. Kumarasingham, Cambridge 2014, s. 137-138. 
gubernator generalny z głębokim żalem musiał skonstatować, że maszyneria konstytucyjna przestała działać" - ogłosiło radio proklamację szefa państwa.

Z tej przyczyny podją decyzję o wprowadzeniu w Pakistanie stanu wyjątkowego. Konstytuanta w obecnej postaci utraciła zaufanie ludu i nie może już funkcjonować. Ostatecznym autorytetem w państwie sa jego mieszkańcy, którzy zadecyduja o wszystkich kwestiach - w tym związanych z konstytucja - za pośrednictwem swych wybranych na nowo reprezentantów. Wybory przeprowadzone zostaną w najwcześniejszym możliwym terminie. Do tego czasu krajem administrować będzie zreorganizowana rada ministrów. [...] Bezpieczeństwo i stabilność kraju to kwestie najwyższej wagi; przed tym najwyższym interesem narodowym ustapić musza wszelkie interesy osobiste, frakcyjne i prowincjonalne ${ }^{79}$.

Te połączone z zamknięciem budynku parlamentu cyniczne słowa - nie było wszak żadnego „chaosu”, jeśli pominąć zagrożenie dla absolutnej władzy Ghulama Muhammada i jego sojuszników, a zarzut, że konstytuanta nie działa, całkiem świeżo stracił aktualność - poprzedziły pełne napięcia negocjacje szefa państwa z politykami i wojskowymi, w tym dramatyczna konfrontacja z Bogra. Pechowo znamy ja głównie z dość podejrzanego źródła - wspomnień Ayuba wydanych za jego dyktatury.

Jak się ona tam rysuje? Już na wieść, że szef państwa kazał całej delegacji w USA wracać do Pakistanu, premier miał zdjęty lękiem spytać generała: „możesz mi zagwarantować, że jak wrócę, nie trafię do więzienia?” W Karaczi Ayub i Mirza (oraz Choudhury Mohammad Ali) zaoferowali się więc, że będa towarzyszyć Bogrze do Ghulama Muhammada, by odwieść tego ostatniego od pochopnych kroków. Na widok Ayuba „paskudny staruch” rozpromienił się i wydobył spod poduszki dokument o treści: „Ja, Ghulam Muhammad, taki i taki, z tego i tamtego powodu przekazuje takie a takie kompetencje gen. Ayubowi Khanowi i nakazuję mu w ciagu trzech miesięcy stworzyć konstytucje”. Jednakże „gdy patrzyłem na owe papiery, wszystko we mnie zakrzyknęło «NIE» i rzekłem: «Swoją lekkomyślnością wyrządzi pan krajowi ogromna szkodę» [...] pojął wreszcie, że nie zamierzam brać udziału w akcie nierozwagi" $"$. Być może, dodajmy, oferenta zainspirowało datowane na 4 września tajne memorandum Ayuba o „obecnych i przyszłych problemach Pakistanu", gdzie domagał się on m.in. pośrednich wyborów - koncept, który zrealizuje jako dyktator - oraz wzmocnienia władzy wykonawczej, gdyż „nieskrępowana demokracja może [...] okazać się groźna, zwłaszcza dziś, gdy komunizm z wewnątrz i zewnątrz śpieszy czynić użytek z jej słabości”"

Rzecz jasna, „mąż stanu nie ulegający pokusie władzy, póki nie zmusi go los ojczyzny” to wręcz leitmotiv autokreacji dyktatorów. O ile sama oferta (choć

\footnotetext{
79 Tekst za: CAP, sixteenth session, 21 IX 1954, s. 572 (nota edytorska).

${ }^{80}$ M. Ayub Khan, op. cit., s. 51-52 (cytat).

${ }^{81}$ Memorandum przedrukowane w: H. Rizvi, op. cit., załącznik A, s. 265-270.
} 
niekoniecznie dokładnie tak sformułowana) z pewnością się pojawiła ${ }^{82}$, to odrzucając ją, Ayub kierował się raczej mniej szlachetnymi pobudkami. W obecnym systemie premier miał mało władzy, a dużo obowiązków. Przyjęcie tej funkcji oznaczałoby zapewne konieczność rezygnacji z dowodzenia wojskiem, choćby z powodów logistycznych - stolicę od kwatery głównej armii w Rawalpindi dzieliło $1500 \mathrm{~km}$ - co otwierałoby pole do działania jego konkurentom. Być może uznał też za niepolityczne wysuwanie się już wówczas na pierwszy plan; pozostając w cieniu, pozwalał, by odium za dewastowanie demokracji spadało na innych (w późniejszym okresie, już jako autokrata, Ayub regularnie podkreślał, że to nie on, a Iskander Mirza wprowadził stan wojenny i zawiesił konstytucję). W efekcie, za namową Mirzy, stanowisko utrzymał wdeptany przedtem w ziemię Bogra: Ghulama Muhammada przekonano, że jest on potrzebny w negocjacjach z USA, a po likwidacji konstytuanty będzie całkiem niegroźny. Istotnie, w następnych miesiącach rola premiera sprowadzała się do nierobienia niczego, co mogłoby szefa państwa zgniewać (spytany rychło przez prasę, czy wspomniana proklamacja formalnie rozwiązywała konstytuantę, odparł: „to jedna z interpretacji. Nie jestem ekspertem prawa konstytucyjnego. Nie wiem" ${ }^{83}$ ).

Jego rząd poddano za to całkowitej reorganizacji. Ayub obją w nim resort obrony, co dało się jeszcze pogodzić z noszeniem munduru. Miesiąc później doproszono też... Suhrawardego, ściagniętego w tym celu ze Szwajcarii. Otrzymał propozycję objęcia teki ministra sprawiedliwości (czytaj: nadzór nad powstawaniem konstytucji) oraz, jak sam potem twierdził, groźbę: w razie odmowy doczeka się militarnej dyktatury z Ayubem na czele ${ }^{84}$. Dobrze to pokazuje przebiegłe metody szefa państwa.

O ironio, jedyna grupa gotową wyjść na ulice w obronie parlamentaryzmu okazali się ulemowie i ich zwolennicy. Zaniepokojeni plotkami, że szef państwa może rozpędzić konstytuantę, ogłosili 22 października „Dniem Konstytucji” w samym Lahore wiecowało wówczas 30 tys. ludzi. Organizatorzy oświadczali: „pewne elementy wysunęły szkodliwy postulat rozwiązania konstytuanty, chcąc w ten sposób osiagnąć swe egoistyczne cele. W istocie chodzi im o unicestwienie islamskiego charakteru konstytucji" ${ }^{85}$. Nie szło bynajmniej tylko o obronę dalece odbiegajacych od marzeń tej grupy religijnych zapisów: ulemowie we własnym gronie mogli marzyć o władzy islamskich „emirów”, ale trzeźwo dostrzegali, że obecna alternatywa to demokratyczny konstytucjonalizm lub świecka dyktatura. Nie było jednak mowy o szerzej zakrojonych protestach: krwawą lekcję z roku 1953 dobrze pamiętano.

${ }^{82}$ Zob. np.: A. McGrath, op. cit., s. 131.

${ }^{83}$ Cyt. za: ibidem, s. 136.

${ }^{84}$ Memoirs of Huseyn Shaheed Suhrawardy with a Brief Account of His Life and Work, ed. M.H.R. Talukdar, Karachi 2009, s. 86-87. Być może - brak o tym wzmianki - próbował on też uzyskać dla Bengalu Wschodniego akceptowalnego gubernatora. Jeśli tak, Ghulam Muhammad (zob. dalej) spełnił tę prośbę w sposób nader przewrotny.

${ }^{85}$ Cyt. za: A. McGrath, op. cit., s. 129. 
Pytanie, czemu nie protestował prawie nikt inny. Nie bez znaczenia był fakt, że szef państwa z początku szafował obietnicami i słodkimi słowami zdawał sobie sprawę, że nie może się powaśnić jednocześnie z konstytuanta i resztą cywilnej opozycji, jeśli chce zachować choćby fasadę republikani$\mathrm{zmu}^{86}$ (stąd podobne co Suhrawardy propozycje otrzymało też paru innych odsuniętych w ostatnich latach polityków). Główny powód był wszelako innej natury. „Członkowie zgromadzenia mieli może formalne prawo do piastowania stanowisk, ale nie moralne [...]. Choć miałem pełną świadomość, że to, co [Ghulam Muhammad] zrobił, było złe, jednak się cieszyłem - ta konstytuanta wcale nie myślała dać krajowi konstytucji” Mujiba. Zważywszy na to, że o całej sprawie dowiedział się on w więzieniu, gdzie wysłał go niedawno Iskander Mirza - obecnie z pewna tylko przesada twierdzący, iż „95\% Pakistańczyków było przeciwnych temu, co działo się w parlamencie" 88 - podobna niechęć musiała być wówczas powszechna. $\mathrm{W}$ istocie potwierdzaja ja $\mathrm{i}$ inne memuary.

Ale nawet i ona nie tłumaczy ogromu poparcia, jakiego doczekał się gubernator generalny od polityków, włącznie z entuzjastycznym przyjęciem w Dakce. Po prostu ze względu na dotychczasowy bilans prac parlamentu w obecnych ruchach tego ciała widziano głównie chęć utrzymania dostępu do fruktów władzy, zresztą bez wątpienia niezmyśloną. Utrwalenie poprawek oznaczałoby, że konstytuanta mogłaby drogą wotum nieufności odwołać Bogrę i zastapić go kimś z własnego grona. Wraz z wejściem w życie ustawy zasadniczej przestałby istnieć urząd gubernatora generalnego, a że prezydenta miał wybierać parlament, przez następne pięć lat głową państwa byłby ktoś z tego grona - może sam Tamizuddin. Kimkolwiek nie byliby dwaj elekci, wraz z kolegami posłami rządziliby też krajem niepodzielnie aż do wyborów, które ostrożnie typowano najwcześniej na początek 1956 r. ze względów organizacyjnych. Zresztą dlaczego, dysponując władzą wykonawcza i ustawodawcza, parlamentarzyści nie mieliby jeszcze odwlec głosowania?

W efekcie grupa skompromitowanych, pozbawionych poparcia polityków utrwaliłaby swoją dominację na lata ${ }^{89}$. Z tej perspektywy krok Ghulama

${ }^{86}$ Na przykład Hamidul Huq Chowdhury, polityk bengalski, którego w 1952 r. odsunięto od urzędów i pozbawiono mandatu poselskiego na mocy PRODA, obecnie został zaproszony do willi Ghulama Muhammada i doczekał się wylewnego przyjęcia: „wstał on z trudem [z wózka], by mnie objąć. Przeprosił za spiski przeciw mnie i przysiagł na Allaha i Koran, że nigdy nie wspierał tych działań, że podjęła je odsunięta przez niego koteria ministrów oraz Liaquat Ali Khan”. Hamidul Huq Chowdhury, op. cit., s. 159.

87 Sheikh Mujibur Rahman, op. cit., s. 280.

${ }^{88}$ Cyt. za: A. McGrath, op. cit., s. 135.

${ }^{89}$ Stąd dyplomaci brytyjscy w działaniach konstytuanty widzieli głównie akt „determinacji kasty polityków, by ubiec każdą próbę ochrony kraju przed ich grabieżczą działalnościa, odsunięcia ich wciąż przedłużającej swą władzę oligarchii”. NA, DO 35/5111, Murray do Morleya, 24 IX 1954, s. 7. Nie dziwota, że gdy Ghulam Muhammad prawował się później z Tamizuddinem o legalność rozwiązania parlamentu, ostrożniejszy od swych reprezentantów 
Muhammada, połączony z zapowiedzią szybkich wyborów, mógł się wydawać bardziej obiecujaccy nie tylko dla karier liderów Zjednoczonego Frontu, lecz i dla demokracji - zwłaszcza że gubernator generalny stał nad grobem i nie posądzano go o możność utrzymania władzy na dłuższą metę, nawet gdyby spróbował. Choć sami bengalscy politycy utrzymywali potem, że byli po prostu realistami - wiedząc, iż to Ghulam Muhammad dzierży obecnie realną władzę, próbowali nastroić go pozytywnie, by wytworzyć wrażenie, że prawdziwie demokratyczne wybory nie zagrażaja jego pozycji.

Ten był jednak zbyt przebiegłym wyga, by owa amikoszoneria uśpiła jego czujność. Politycy spoza jego otoczenia, których zaprosił do rządu, zostali przezeń błyskawicznie wymanewrowani - poczynając od Suhrawardego, który szybko zdał sobie sprawę, że politycznie nie ma nic do powiedzenia, zwłaszcza w sprawie konstytucji. Władzę szefa państwa ograniczało już $\mathrm{w}$ istocie tylko wojsko...

...a przynajmniej tak mogło mu się zdawać do 9 II 1955 r. Sąd Najwyższy (High Court) prowincji Sind przychylił się wówczas do pozwu Tamizuddina Khana, żądającego stwierdzenia, że rozwiązanie konstytuanty nie posiada mocy prawnej. Przewodniczący składu sędziowskiego (który ponoć musiał przekradać się do sądu przebrany w burkę, by ominać mających go zatrzymać policjantów) nie zostawił na dekrecie Ghulama Muhammada suchej nitki ${ }^{90}$. Rozradowany Tamizuddin - nie przejmując się, że następnego dnia Iskander Mirza zapowiedział szybkie przyjęcie „zdrowej konstytucji” i „stanowcze działania” w razie „nieporządku” 91 - wyznaczył szybko nowe posiedzenie parlamentu na marzec $^{92}$, jednak szanse na nie pogrzebał nowy krok gubernatora generalnego.

Londyn musiał wyraźnie tłumaczyć Laithwaite’owi, że nie jest jego rolą pomagać szefowi państwa w szukaniu przepisów, na które ten mógłby się powołać w sądzie (otoczenie Wysokiego Komisarza i tak zresztą nie umiało ich znaleźć). NA, DO 35/5115, T.W. Keeble (CRB) do Laithwaite'a, 26 XI 1954, s. 16.

90 Sentencja wyroku: S.S. Pirzada, Dissolution of Constituent Assembly of Pakistan and the Legal Battles of Moulvi Tamizuddin Khan, Karachi 1995, s. 116-127 (na s. 53-54 relacja na temat epizodu z burka; w podobny sposób musiał się przedtem wymykać z domu, przechytrzając mundurowych, Tamizuddin, którego próbowano powstrzymać od wniesienia sprawy do sądu. Tamizuddin Khan, The Test of Time. My Life and Days, Dhaka 1989, s. 151). Pełne dossier procesu: NA, DO 35/5115; zob. też: A. McGrath, op. cit., s. 95-96. Nota bene wśród dyplomatów kursowały wówczas plotki, że niekorzystny dla szefa państwa wyrok sindzkiego sądu pociąnie za sobą stan wojenny. NA, DO 35/5115, J.R.A. Bottomley (WK) do T.W. Keeble'a (CRB), 12 XI 1954, s. 14a.

${ }^{91}$ Ibidem, Wyciag z raportu nt. sytuacji w Pakistanie 4/2/55-17/2/55, s. 28a.

${ }_{92} \mathrm{~W}$ tym czasie miała ponoć miejsce szczególna intryga: Tamizuddin i Bogra umówili się, że jeśli sindzki sąd orzeknie na korzyść konstytuanty, premier przekaże w Londynie Elżbiecie II prośbę o odwołanie gubernatora generalnego. Bogra poczynił już przygotowania w tym kierunku, ale w brytyjskiej stolicy zjawił się też Iskander Mirza i „co zaszło między nimi, nie wiadomo", lecz w każdym razie szef rządu porzucił swój zamiar. Cała rzecz znana jest jednak tylko z późnej relacji jednego ze współpracowników Tamizuddina (S.S. Pirzada, op. cit, s. 59) i wymaga dalszych badań źródłowych. 
Ten zaś złożył apelację do Sądu Najwyższego kraju (Supreme Court). W nim mógł liczyć na większą przychylność wyrokujących, bo też zawczasu o nia zadbał: w połowie $1954 \mathrm{r}$. przewodniczacym tego ciała, na miejsce emerytowanego poprzednika, został Munir (który dotąd w ogóle w nim nie zasiadał; tym samym zignorowano zwyczaj, by powierzać ów urząd najstarszemu z dotychczasowych sędziów). Dał się on poznać jako człowiek Ghulama Muhammada już w 1948 r., gdy przewodnicząc komisji ds. płac służb cywilnej, popierał ówczesnego ministra finansów przeciw Liaquatowi (i Choudhury'emu Mohammadowi Alemu) ${ }^{93}$. Trzeba przy tym zauważyć, że obaj wywodzili się z tego samego pasztuńskiego klanu Kakazai; w Pakistanie takie więzi znaczyły często więcej niż podziały frakcyjne ${ }^{94}$. Toteż nawet Brytyjczycy spodziewali się, że „wyjdzie on poza ciasny gorset względów czysto prawnych"95.

$\mathrm{Na}$ tym zakulisowe zabiegi szefa państwa się nie skończyły. Usunął sprytnie z drogi sędziego Muhammada Shahabuddina, w którym widział przeciwnika - proponując mu po prostu stanowisko... p.o. gubernatora Bengalu Wschodniego, co oczywiście oznaczało czasowy urlop z sadu. Wydaje się, że sędzia przystał na to, chcąc pomóc Bengalczykom (sam urodził się w Madrasie, ale wiele lat pracował w Dakce) po brutalnych rządach Iskandra Mirzy. Shahabuddin ostatecznie złożył urząd i wrócił do orzekania, ale dopiero po upadku Ghulama Muhammada. Chwilowo na jego czasowego zastępcę wyznaczono Sheikha Abdura Rehmana, prezesa Sądu Najwyższego Pendżabu, protegowanego Munira. Że szło o wybór kandydata, któremu szef państwa mógłby zaufać, pokazuje choćby data jego nominacji - 3 III 1955 r., krótko przed rozpoczęciem obrad nad pozwem Tamizuddina.

Jednocześnie z nimi (sic!) Munir próbował mediacji. Tamizuddin zaproponował, by Ghulam Muhammad pozwolił konstytuancie zebrać się na nowo, a ta nie promulguje ustawy zasadniczej, lecz przyjmie ustawę o wyborach do nowej konstytuanty w oznaczonym terminie ${ }^{96}$. Gubernator generalny odrzucił pomysł, tłumacząc, że mógłby traktować Tamizuddina jako reprezentanta posłów, tylko jeśliby ten zebrał podpisy dwóch trzecich z nich pod upoważnieniem. Jako prawdziwy powód badacze sugeruja obawę, że jeśli parlament się zbierze, niekoniecznie poczuje się związany obietnica przewodniczącego ${ }^{97}$ - ale też nowa konstytuanta ze świeżą, niepodważalna legitymacja w ogóle nie byłaby szefowi państwa na rękę. Munir, który wyraźnie wolałby się trzymać z boku całego sporu, narzekał, że musi sądzić sprawę o charakterze $\mathrm{w}$ istocie nie prawnym, a politycznym. Tyle że to była

\footnotetext{
${ }_{93}$ A. McGrath, op. cit., s. 188-189, 195.

${ }^{94}$ Hamid Khan, Constitutional and Political History of Pakistan, Oxford 2005, s. 88, 100.

${ }^{95}$ NA, DO 35/5115, J.M.C. James (WK) do Phillipa Swintona [sekretarza ds. Wspólnoty Narodów], 16 II 1955, s. 79a.

96 „Times”, 4 III 1955.

97 A. McGrath, op. cit., s. 175; S.S. Pirzada, op. cit., s. 59-63.
} 
jego ocena. W efekcie faktycznie sprokurował wyrok bardziej polityczny niż legalistyczny.

21 marca Sąd Najwyższy odrzucił pozew Tamizuddina 4 głosami przeciw 1 (zdanie odrębne złożył Alvin Robert Cornelius). Nie mniej istotne od samego werdyktu było jego uzasadnienie: zamiast odnosić się do meritum sprawy, sięgnięto po prawny kruczek. Akt o rządzie Indii zawierał stwierdzenie, że gubernator generalny ma władzę zatwierdzenia dowolnej ustawy (,has the power to give assent to any law"), z czego wedle sentencji wyroku wynikało, iż bez jego podpisu ustawa jest nieważna. A ustawy, na która powołał się sindzki sąd, szef państwa nie parafował!

Tyle że ów brak podpisu nie został przeoczony. To, że sygnowanie ustaw przez szefa państwa nie jest konieczne do ich wejścia w życie, stanowiło po prostu praktykę utarta jeszcze za Jinnaha ${ }^{98}$. Gubernatorzy generalni podpisywali więc kopie nowych praw, gdy im się chciało - od początku istnienia państwa nie chciało im się zaś w 46 przypadkach. I tyleż ustaw nowa wykładnia prawa implicite unieważniła.

Sędziowie - co jasno wynika z treści wyroku - mieli pełną świadomość, że otwieraja puszkę Pandory: „Jeśli wskutek tego [zmiany statusu ustaw] nastapi katastrofa, będzie to tylko [sic!] kolejny dowód, jak bezmyślnie poczynała sobie konstytuanta i w jakie kłopoty wpędziła kraj przyznajac sobie status nieusuwalnego parlamentu" 99 . W tym momencie nawet natychmiastowe sygnowanie przez szefa państwa unieważnionych przepisów nie rozwiązałoby problemu - co z orzecznictwem już wydanym na ich podstawie? Czy np. bank państwowy w ogóle funkcjonuje legalnie, skoro z prawodawstwa wycięto ustawę, na mocy której powstał?

O ile więc po wyroku Ghulam Muhammad ponoć „odmłodniał o dziesięć lat" ${ }^{100}$, Pakistan staną na progu chaosu, co najlepiej pokazuje przykład konspiratorów z Rawalpindi: sąd musiał wypuścić ich z aresztu (choć wkrótce zostali uwięzieni na nowo), bowiem do podważonych praw należał akt powołujący specjalny trybunał, który ich skazał. Gubernator generalny postanowił obejść kłopot, nadając dekretem 27 marca wsteczną sankcję większości (35) zakwestionowanych ustaw, pomijając kilka niewygodnych - np. tych przyjętych podczas ostatniego posiedzenia parlamentu ${ }^{101}$.

Ivor Jennings, rzeczywisty autor samego dekretu, zaznaczył we wspomnieniach, iż jego tekst konsultowany był z Munirem. W ostatniej chwili Ghulam

98 Warto nadmienić o istotnym drobiazgu: wspomniany tu sędzia Shahabuddin w jednym z wyroków orzekł niegdyś, że podpis taki jest zbędny. A. McGrath, op. cit., s. 197.

${ }_{99}$ Sentencja wyroku przedrukowana w: Chief Justice Muhammad Munir. His Life, Writing and Judgments, ed. N.C. Chaudhry, Lahore 1973, s. 261-346 (cytat: s. 326).

100 NA, DO 35/5116, Laithwaite do Foreign Office, 23 III 1955, s. 124. Podkreślana tu „ogromna ulga" szefa państwa stanowi moim zdaniem przesłankę, że niekoniecznie był on gotów na siłową interwencję przy innym obrocie spraw.

101 Tekst dekretu w: NA, DO 35/5116, s. 133. 
Muhammad dodał doń jednak stwierdzenie, że nowa konstytuanta zostanie wyznaczona przez niego ${ }^{102}$. Dla niektórych nie stanowiło to zaskoczenia. Mirza, publicznie raczacy prasę wynurzeniami, iż pakistańskie „masy” sa „, przytłaczającej większości niepiśmienne i nie obchodzi ich polityka"103 (czytaj: i tak nie umiałyby wybrać właściwych ludzi), więc krajowi trzeba „demokracji kierowanej”, która m.in. oddzieli religię od państwa ${ }^{104}$, już w grudniu zwierzył się ambasadorowi USA, że konstytucję stworzyć ma utworzona przez władze „konwencja”. Ta następnie się rozwiąże i „obecny gabinet będzie rządził bez parlamentu przez dwa lata, do czasu wyborów powszechnych"105.

Ów plan pokrzyżowała tzw. sprawa Usifa Patela. Był on jednym z trzech drobnych opryszków z Sindu, którzy parę miesięcy wcześniej zaskarżyli swe wyroki i których apelacje trafiły obecnie przed Sąd Najwyższy. Ich adwokaci przekonywali, że całą trójkę należy zwolnić, bowiem stanowiąca podstawę ich uwięzienia ustawa również nie otrzymała w odpowiednim czasie podpisu gubernatora generalnego, a próbując to poniewczasie zmienić dekretem, szef państwa przekroczył swe uprawnienia. Sędziowie podzielili to zdanie jednogłośnie, 12 kwietnia stwierdzajacc, iż „w sprawie Tamizuddina Khana nie uważaliśmy za konieczne wyrokować, czy rozwiązanie konstytuanty miało moc prawną, ale nawet jeśli, to z pewnością nie pociagało za sobą przekazania

102 Że prawny kształt poprzedniego wyroku władze również uzgodniły zawczasu z Munirem, sugeruje inny fragment wspomnień Jenningsa, który zanotował: „Wezwano mnie, bym doradził [w tej sprawie] rządowi; doszedłem do wniosku, że nie mamy wielkich szans na sukces, chyba że podamy w wątpliwość ważność wszystkich ustaw promulgowanych przez konstytuantę na podstawie faktu, iż wymagały one - a nie otrzymały - podpisu gubernatora generalnego" - dokładnie ta linia orzecznictwa, która przyją Sąd Najwyższy. Constitution-Maker..., s. 137, 138 (cytat). Dobrze komponuje się to z podaną po latach przez Qudratullaha Shahaba, ówczesnego sekretarza gubernatora generalnego, informacja, że jeden z jego asystentów służył za pośrednika w zakulisowych kontaktach szefa państwa z Munirem (Hamid Khan, op. cit., s. 88); wiadomo również, że w czasie rozpatrywania sprawy Ghulam Muhammad co najmniej raz odwiedził sędziego w domu, wcale się z tym nie kryjac (A. McGrath, op. cit., s. 196).

${ }^{103}$ Cyt. za: E. Iob, A Betrayed Promise? The Politics of the Everyday State and the Resettling of Refugees in Pakistani Punjab, 1947-1962, [niepublikowana praca doktorska obroniona na Royal Holloway, University of London], 2013, s. 220 (korzystałem z wersji internetowej: https://repository.royalholloway.ac.uk/file/64d284d0-34e2-0a48-a6a0-2dbb6a83c5ba/7/ Elisabetta_Iob_PhD_DIssertation.pdf [dostęp: 26 II 2008]). Warto polecić całość tego znakomitego dzieła.

${ }^{104}$ Cyt. za: L. Binder, op. cit., s. 361.

105 NAPW, „Current Intelligence Bulletin”, 24 XII 1954. Zadowoleni z tych wywodów Brytyjczycy wyrażali nadzieję, że nowe władze, ,jak Iskander Mirza” w Bengalu Wschodnim, „poprawią i byt materialny, i morale prostego człowieka”. NA, DO 35/5115, Murray do Morleya, 28 X 1954, s. 9. Do rozmowy z Mirzą o tym, że tego rodzaju siedzenie na bagnetach na dłuższą metę podminuje państwo, przymierzał się za to ambasador USA Hildreth (teść jego syna!), ale zabronił mu Departament Stanu, nie chcąc sprawiać wrażenia, że miesza się w sprawy Pakistanu i to przeciw swym przyjaciołom. D. Kux, op. cit., s. $75-76$. 
gubernatorowi generalnemu jej kompetencji [...] nie jest on konstytuantą i po jej zniknięciu nie może sobie rościć praw, których nigdy nie miał"106.

Upokorzony szef państwa wyznaczył na 10 maja konwencję konstytucyjna i - uznajacc, że to rozwiąuje problem - wydał kolejny dekret powtarzający resztę założeń pierwszego ${ }^{107}$. Jednocześnie skierował do Sądu Najwyższego prośbę o wytyczne, jak rozstrzygnąć problem utrąconych ustaw - znaną jako Specjalne Zapytanie nr 1 (Special Reference No. 1). Pytano tam: 1) co może i za co odpowiada gubernator generalny przez uchwaleniem niezbędnych praw przez nową konstytuantę, 2) czy istnieje możliwość znalezienia prawnego uzasadnienia, by ustawy wymienione w dekrecie zachowały ważność?, 3) czy gubernator generalny rozwiązał dotychczasowa konstytuantę zgodnie z prawem?, 4) czy przyszła konstytuanta, którą zamierza utworzyć, będzie dysponować władzą legislacyjną?

Odpowiedź wydana 10 maja (zapowiedź „konwencji” wygodnie przesunięto na okres po decyzji sądu ${ }^{108}$ ) była zasadniczo po myśli Ghulama Muhammada, zwłaszcza co do kluczowego drugiego pytania ${ }^{109}$. Gorzej poszło z pierwszym, gdzie udało się uzyskać tylko minimalną większość głosów (przeciw wypowiedzieli się Cornelius i Muhammad Sharif). Munir, reprezentujący ową większość, zaangażował w sprawę właściwy sobie patos: „Stanęliśmy na brzegu przepaści i mamy jedynie trzy drogi: wrócić tam, skąd przyszliśmy, przerzucić nad przepaścia most legalizmu lub rzucić się w nią bez nadziei na ratunek".

Most zaprojektowano nie bez fantazji: $\mathrm{z}$ braku jakichkolwiek precedensów w prawie brytyjskim (czy pakistańskim) mogacych podeprzeć decyzję o rozwiązaniu konstytuanty i złamaniu zasady lex retro non agit Munir sięgną do innych maksym prawa rzymskiego: „co inaczej byłoby bezprawne, konieczność uprawnia”, „najwyższym prawem jest bezpieczeństwo ludu” i „najwyższym prawem jest bezpieczeństwo republiki”"110. Ową „doktrynę konieczności”,

106 Sentencja wyroku przedrukowana w: Chief Justice Muhammad Munir..., s. 347-364 (cytat: s. 352-353).

107 Tekst dekretu: NA, DO 35/5116, s. 165, załącznik.

${ }^{108}$ Ibidem, „Pakistan - Constitutional Developments”, [b.d.], s. 182.

${ }^{109} \mathrm{O}$ ironio, tym razem twierdząco odpowiedział na nie także Cornelius, tłumacząc, że nie może głosować w sposób sprzeczny z rozstrzygnięciem w sprawie Tamizuddina, które jako wyrok Sądu Najwyższego ma moc obowiązującą. Od głosu wstrzymał się za to sędzia Muhammad Sharif.

110 Sentencja wyroku przedrukowana w: NA, DO 35/5116, „Pakistan - Constitutional Developments”, [b.d.], s. 365-422 (pierwszy cytat: s. 369, drugi: s. 410). Jeden z filarów werdyktu stanowiło stwierdzenie, że konstytuanta nie jest ciałem suwerennym, lecz zaczerpnęła swój autorytet od Korony Brytyjskiej, więc mógł ją rozwiązać gubernator generalny jako reprezentant tejże Korony - co, nawiasem mówiąc, było sprzeczne z twierdzeniami Jinnaha, też piastującego to stanowisko. Zob. I. Niaz, Jinnah on governance: The unheeded advice of Pakistan's Quaid-i-Azam, „Asian Affairs” 2016, vol. XLVII, no. 3 (korzystałem z wersji internetowej bez podziału na strony: http://www.tandfonline.com/doi/full/10.108 0/03068374.2016.1225902 [dostęp: 26 II 2008]). 
ignorująca sprzeczności między trzema przytoczeniami, czekała wielka kariera w państwach postkolonialnych.

O ile literatura przedmiotu bardzo obszernie opisuje prawną stronę wyroków ${ }^{111}$, o tyle nie podejmuje kwestii motywów sędziów, którzy nie opowiedzieli się przecież za Ghulamem Muhammadem jednoznacznie. Przy obecnym stanie źródłoznawstwa pytanie to musi częściowo pozostać w sferze domniemań, niemniej da się, jak sądzę, wskazać kilka przesłanek pomocnych w szukaniu odpowiedzi.

Po pierwsze, czymkolwiek kierował się w tym czasie Munir, nie było to raczej zamiłowanie do demokracji - sugerują to jego wcześniejsze poglądy i późniejsze czyny. Po drugie, w pierwszej z trzech omawianych spraw skład sędziowski ewidentnie próbował ominąc sedno - spytać można, czemu, skoro (jak dowodzą słowa o „katastrofie”) nie bał się bynajmniej oskarżeń o sprzyjanie szefowi państwa i niszczenie ustroju. Po trzecie, ostatnią sprawę rozstrzygnięto na korzyśś gubernatora generalnego najmniejszym możliwym stosunkiem głosów - $3: 2$. Po czwarte, w drugiej sprawie - przeciw Ghulamowi Muhammadowi - opowiedzieli się jednogłośnie wszyscy, mimo że Munir był przedtem pewien, iż uzyska aprobatę dla dekretu - powód mogło stanowić tylko wykreślenie zapowiedzi wyborów.

Najbardziej prawdopodobna wydaje mi się następująca hipoteza: stronnicy gubernatora generalnego - Munir i Sheikh Abdur Rehman - nie mieli większości. Pryncypialny sprzeciw napotkali ze strony szczerze oddanego demokracji sędziego Corneliusa, dwaj pozostali zaś byli gotowi poprzeć rozwiązanie konstytuanty - politycznie stanowiącej anomalię z zakresu „demokratury”, do tego osłabionej masową dezercja posłów do obozu władzy - ale po to, by rozpisano nowe wybory. W pierwszej sprawie pozyskano ich sentencja wyroku, która nie przesądzała o legalności decyzji szefa państwa - jego krok miał pozostać nie realizacja praw władzy wykonawczej, lecz anomalia, nad która przechodzi się do porządku dziennego dla większego dobra. Takie postawienie sprawy mogłoby skłonić władze do szybkich wyborów - nowy, prawdziwie demokratyczny parlament uciąłby raz na zawsze pretensje starego. W drugiej sprawie Munir z Rehmanem nie mieli już żadnych argumentów, więc poszli razem $\mathrm{z}$ większościa - $\mathrm{w}$ obawie przed przegłosowaniem i/lub przed tym, że Ghulam Muhammad nie pytajac nikogo o zdanie, uzurpuje sobie kompetencje władzy wykonawczej, a niepowstrzymany może zrobić to samo z sądowniczą. Potwierdzenie, że interpretowanie prawa należy do sądów, i mglista zapowiedź nowych wyborów pomogły przeciagnąć na stronę władz jednego z sędziów, ale tylko jednego.

${ }^{111}$ Najbardziej drobiazgowe analizy w: Syed Sami Ahmad, Tamizuddin Khan's Case. The Judgment that Brought Disaster, Karachi 1991, passim; A. McGrath, op. cit., s. 155-217; P. Newberg, Judging the State. Courts and Constitutional Politics in Pakistan, Cambridge 2002, s. 42-68. 
Inna alternatywa, która wydaje mi się dopuszczalna, jest taka: grupa sędziów przychylnych Ghulamowi Muhammadowi od początku działała z zamiarem potwierdzenia jego decyzji, ale w taki sposób, żeby pozostał on zdany na decyzje sądu. Gdyby po prostu uznano legalność rozwiazania konstytuanty, gubernator generalny działałby, jak chciał; tymczasem w obliczu chaosu prawnego musiał występować wobec najwyższej judykatury z pozycji petenta zwracającego się o naprawę sytuacji. To dlatego sąd najpierw rozstrzygną na jego niekorzyść pozew Usifa Patela, a potem sformułował „doktrynę konieczności” w taki sposób, by to sędziom przypadała formalna decyzja, kiedy konieczność zachodzi.

Na pewno jednak powody decyzji sędziów nie były takie, jak tłumaczył je kilka lat później Munir na zebraniu izby adwokackiej w Lahore (22 IV 1960), gdy zbierał się już do odejścia ze stanowiska. Jak tłumaczył, nie mógł wydać innego wyroku z przyczyn moralnych; w wypadku otwartego sprzeciwu wobec władzy Ghulama Muhammada - de facto jedynej, jaka w kraju istniała mogłaby się polać krew. „Psychiczna udręka, której te sprawy przysporzyły sędziom, jest nie do opisania i nigdzie indziej na świecie sędziom nie przyszło przechodzić przez coś takiego - coś, co można by określić mianem tortury sądowej”"112. Gdy jednak mimo owych tortur sędziowie sprzeciwili się szefowi państwa w sprawie Usifa Patela, żadnego rozlewu krwi nie było; przeciwnie, Ghulam Muhammad pokornie zwrócił się do sądu o pomoc w wybrnięciu z klinczu. W moim przekonaniu sugeruje to, że szef państwa nie czuł się wówczas na siłach podeptać postanowień władzy sądowniczej, być może nie majac $\mathrm{w}$ tej kwestii poparcia wojska. A komu jak komu - Munirowi układ sił we władzach był bez watpienia znany ${ }^{113}$.

Włącznie z rosnacym wpływem Iskandra Mirzy. W 1955 r. w nadal nieznanych okolicznościach wymusił on dymisję zarówno dogorywającego Ghulama Muhammada, jak i premiera Bogry; nowym gubernatorem generalnym mianował sam siebie, szefem rządu zaś - Choudhury'ego Mohammada Alego. Pod koniec rządów Ghulam Muhammad zdążył jeszcze powołać nowy parlament wybrany nie przez obywateli, lecz prowincjonalne ciała ustawodawcze - który po przejęciu władzy przez Mirzę promulgował w kilka miesięcy ustawę zasadnicza.

112 Tekst przemówienia w: Chief Justice Muhammad Munir..., s. 14-25 (cytat: s. 20). Munirowi uwierzył na słowo Syed Adnan Hussain (op. cit., s. 153; warto też przeczytać w całości poświęcony sędziemu rozdział IV tej pracy, przynoszący interesujące uwagi na temat światopoglądu Munira, ale zupełnie nieprzekonujący jako rekonstrukcja związku jego idei z myśla Jinnaha i politycznego kontekstu jego działań). Autorowi niniejszych słów bliżej do Hamida Khana, który uznał te słowa za „kulawe wykręty człowieka winnego”. Hamid Khan, op. cit., s. 89.

${ }^{113} \mathrm{Na}$ pewno lepiej niż Suhrawardemu, który jako minister sprawiedliwości zaproponował wówczas szefowi państwa: a) powołanie się na art. 95 Aktu o Rządzie Indii, wedle którego gubernator generalny może przejać pełnię władzy legislacyjnej, b) zignorowanie wyroku sądu albo c) narzucenie przez szefa państwa nowej konstytucji dekretem. NA, DO 35/5116, Memorandum Suhrawardego, 13 IV 1955, s. 155. 
Lata pomiędzy tą zmianą warty a zamachem stanu w 1958 r. dokonanym przez Mirzę - którego przyjęcie konstytucji uczyniło z gubernatora generalnego prezydentem o nader szerokich uprawnieniach - sa pod wieloma względami równie źle zbadane co okres wcześniejszy. Wiadomo jednak, że zasadniczy przełom - emancypacja wojska spod cywilnej kurateli - nastapił wcześniej i Suhrawardy, jedyny w tym okresie premier (IX 1956 - X 1957) cieszacy się niezależną od ośrodka prezydenckiego silną bazą polityczna, usłyszał na wstępie od Mirzy, by nawet nie próbował mieszać się w sprawy armii ${ }^{114}$; tym bardziej nie mieli takich możliwości jego następcy. Wiadomo tė̇, że do nacisków wojska, biurokracji i elit ziemiańskich dołożyły się wówczas bolączki właściwe młodym demokracjom, dobrze znane z II RP - zwyczajny w systemie wielopartyjnym korowód koalicyjnych targów sprawiał wrażenie żenującego kupczenia państwem przez polityków, którym nawykli do pewnej stabilności władz ludzie przestawali ufać. Nie wiadomo natomiast, czy resztki parlamentaryzmu postanowił w końcu obalić sam Mirza, czy pchał go do tego Ayub (jego deklaracja, którą cytuję na początku, nie musi rzecz prosta odpowiadać prawdzie) $)^{115}$.

Ostatecznie mianowany przez Mirzę po bezkrwawym puczu głównym administratorem stanu wojennego Ayub pozbył się go po trzech tygodniach, wysyłając samolotem do Londynu. A władzę nowego dyktatora, której dopiero po pięciu latach nadano parlamentarną fasadę, już w $1960 \mathrm{r}$. zalegalizował wyrokiem Munir - zreszta na marginesie zupełnie innej sprawy. Zaskarżono w niej archaiczną ustawę regulująca szereg aspektów życia niektórych plemion pogranicza jako niezgodna z konstytucja z $1956 \mathrm{r}$. Munir orzekł, iż konstytucja ta utraciła ważność, gdyż „rewolucja jest uznaną międzynarodowo metodą zmiany rządu", co miało wynikać z pism teoretycznych austriackiego filozofa prawa Hansa Kelsena. Na patrona tych poglądów lepiej nadawałby się jednak wielki wróg tamtego, Carl Schmitt ${ }^{116}$.

Wiele lat później, za rządów fundamentalistycznego dyktatora Zii ul-Haqa (który skądinąd legitymizując swą władzę, sięgną m.in. po powyższy werdykt), spod pióra Munira spłynęła poczytna do dziś książka From Jinnah to Zia.

${ }^{114}$ A. Jalal, op. cit., s. 254.

${ }^{115}$ Niejasne jest m.in., czy bezpośredni pretekst przewrotu - bunt chana Kalatu (przyłączonego do Pakistanu w 1948 r. pod groźbą użycia wojska) - nie był wynikiem intrygi Mirzy, jak twierdził później sam chan. Z drugiej strony mógł po prostu chcieć się wybielić. Zob. M.A.Y.K. Baluch, Inside Baluchistan. A Political Autobiography of His Highness Baiglar Baigi, Khan-e-Azam-XIII, Karachi 1975, s. 167-180.

116 Z olbrzymiej literatury poświęconej sprawie Dosso kontra Pakistan (która nie uszła uwagi innych autokratów w państwach postkolonialnych) trudno nawet coś wybrać. Względnie nowe omówienie tematu zob. Z. Nikolić, R.B. Baker, Between Politics and Science: The Dilemma of Reason, „The Journal Jurisprudence” 2014, vol. XXII, s. 92-96 (korzystałem z wersji internetowej: http://www.jurisprudence.com.au/juris22/juris22.pdf [dostęp: 26 II 2008]). Szereg ciekawych uwag także w: S.C.R. McIntosh, Kelsen in the „Grenada Courts”. Essays on Revolutionary Legality, Kingston 2008, s. 137-151. 
Przedstawia ona dzieje kraju jako nieprzerwany bój sił świeckości i tolerancji z siłami agresywnego islamizmu, co pozwala autorowi umieścić się całkowicie po stronie „dobrych”. O demokracji nadmieniono tylko, że niestety nie przyjęła się w Pakistanie z powodu niedemokratycznych skłonności polityków, a przykłady to - aż trudno uwierzyć - Ghulam Muhammad, Iskander Mirza i Ayub!117

Tymczasem przytoczony na wstępie cytat z dziennika tego ostatniego moim zdaniem rozstrzyga spór, kim w istocie był Munir - nie, jak wciąż chce wielu badaczy, „radykalnym pozytywista”, a tym bardziej „nadzwyczajnym umysłem prawnym oddanym wdrażaniu prawa tak, jak je rozumiał [...] czyli jako narzędzia dla utrzymania porządku”"118. I nawet nie „realista”, który ugiał się przed siłą ${ }^{119}$. Był po prostu poputczikiem kolejnych „silnych ludzi” zwalczających demokrację, którym starał się stworzyć warunki do działania (i których opuszczał, gdy tracili wpływy). Trudno bowiem zakładać, że człowiek, który w 1958 r. chciał dla obalenia demokracji chaos pogłębiać, cztery lata wcześniej miał jego uniknięcie za główną troskę. Dość prawdopodobne natomiast, że jakąś rolę odegrała tu twarda niechęć jego kandydatów na zbawców narodu do integrystów, a prawdę mówiąc, do wszystkich szczerych zwolenników powoływania się na zasady islamu w prawie państwowym.

Jeśli i takie były motywy sędziego, trudno nie wskazać, że przystając na poświęcenie demokracji w imię świeckości doczekał się - jak zwykle bywa w podobnych wypadkach - braku i demokracji, i świeckości. Pod pewnymi względami był typowym reprezentantem wcale licznej grupy w postkolonialnych elitach pakistańskich, które „na ogół dysponowały niezbyt wielka, jeśli w ogóle, systematyczną wiedzą na temat islamu. Jedyne, co wiedzieli o nim z cała pewnościa, to że przemawiał do gorzej wykształconych Pakistańczyków, ci zaś często podążali za demagogami, których wizja państwa była dogłębnie antyliberalna" ${ }^{120}$. Zwalczając jako konia trojańskiego integryzmu odniesienia do religii w prawie i retoryce politycznej, wrzucano więc islam liberalny - tak jak rozumieli go Liaquat i chyba Jinnah - do jednego worka z poglądami JI. Efekt okazał się dokładnie przeciwny zamierzonemu - podejście takie oddało radykałom pole w definiowaniu, czym jest islam, który wszak wciąż stanowił praktycznie jedyne ideowe spoiwo państwa ${ }^{121}$. Na Pakistanie miało się to wkrótce srodze zemścić.

${ }_{117}$ M. Munir, From Jinnah to Zia, Lahore 1980, s. X-XI (przedmowa nieobecna w pierwszym wydaniu).

118 Syed Adnan Hussain, op. cit., s. 154-155.

119 P. Newberg, op. cit., s. 13.

120 C. Lombardi, Islamism as a Response to Emergency Rule in Pakistan: the Surprising Proposal of Justice A.R. Cornelius, w: Emergency Powers in Asia. Exploring the Limits of Legality, ed. V.V. Ramraj, A.K. Thiruvengandam, Cambridge 2010, s. 461. Lombardi pisał w zupełnie innym kontekście i o latach sześćdziesiątych, ale w odniesieniu do poprzednich kilkunastu lat słowa te są równie prawdziwe.

${ }^{121}$ Tak np.: Seyyed Vali Reza Nasr, op. cit., s. 138-139. 
Rzecz jasna nie jest łatwo orzec, czy dałoby się tego uniknać, gdyby Ghulam Muhammad nie znalazł większościowego poparcia w Sązie Najwyższym. Czy cofnąłby się, gdyby obalono jego dekret? Czy Iskander Mirza i Ayub Khan byliby już wtedy gotowi interweniować siła? Nie wiadomo ${ }^{122}$, przynajmniej jednak dwie rzeczy rokowały wówczas pomyślniej dla demokracji niż w roku 1958: po pierwsze, wiązano z nią większe nadzieje - Pakistan nie miał wszak dotąd żadnego parlamentu z realnym poparciem - po drugie zaś, potencjalny dyktator musiałby iść na wojnę z całym ustrojem, gdy Mirza, a po nim Ayub mogli być pewni wsparcia najwyższej judykatury i w konsekwencji listka figowego dla autorytaryzmu.

Mniej problematyczne, choć problemy z bazą źródłowa pozwalają tylko na odpowiedź dość ogólna, jest pytanie, jakim przyczynom i w jakiej kolejności przypisać kryzys konstytucyjny oraz związane z nim fiasko pierwszej (a w długofalowej konsekwencji chyba także następnych) demokracji pakistańskiej. Dużo mniej istotny, niż się często przyjmuje, projektując na przeszłość obecny węzłowy konflikt Pakistanu, był czynnik religijny; waśnie etniczne, choć przyczyniły się do podminowania państwa, także nie miały charakteru decydującego. Przesądziły o tym kwestie ustrojowe - trudno znaleźć mutacje demokracji mniej odpowiednią dla wchodzącego w niepodległość kraju niż westminsterska, oparta w sporej mierze na niepisanym obyczaju - oraz polityczne. Gdy znikło „naturalne” przywództwo w osobach Jinnaha i Liaquata, różne frakcje Ligi natychmiast zaczęły ryć pod sobą nawzajem i rychło doszło do zaburzenia trójpodziału władzy, w czym władza wykonawcza i sądownicza szły ręka w rękę przeciw ustawodawczej; walka ta skompromitowała wszystkie trzy do tego stopnia, że przynajmniej początkowo przejęcie rządów przez wojsko nie spotkało się z większą niechęcią zmęczonego ich podchodami społeczeństwa. A jeszcze spiskowcy z 1950 r. wyraźnie bali się i kontrakcji innych oficerów, i chyba również ulicy. Osiem lat później mało kto wiedział, czego właściwie można by bronić.

${ }^{122}$ Odpowiedzi na to pytanie próbował szukać Allen McGrath. Spośród jego rozmówców Amjad Ali, ówczesny minister finansów, zapewniał, że Ghulam Muhammad uszanowałby werdykt sądu, natomiast sędzia Nasim Shah, jeden z młodszych członków zespołu rządowego mierzącego się ze sprawą Tamizuddina, twierdził odwrotnie, podobnie jak - to już moje ustalenie źródłowe - Suhrawardy, choć on mówił o dekrecie z marca (NA, DO 35/5116, A.C.B. Symon [WK] do Saville'a Garnera [CRB], 29 III 1955, s. 136). McGrath $\mathrm{w}$ przeciwieństwie do mnie opowiedział się za drugą wersja, co wynika m.in. z odmiennej interpretacji źródeł: zachowane w nich, a przypisywane Jenningsowi memorandum na temat możliwości wprowadzenia dyktatury wbrew orzeczeniu sądowemu autor ten bierze za wyraz poglądów gubernatora generalnego. W moim przekonaniu było ono tylko głosem doradczym tego, kto je napisał. A. McGrath, op. cit., s. 268, 274. 


\section{Streszczenie}

W latach 1953-1955 w Pakistanie uległ praktycznej likwidacji ustrój odziedziczony po jego założycielu Muhammadzie Alim Jinnahu, co w ostatecznym rozrachunku doprowadziło do ustanowienia w 1958 r. dyktatury. Pierwszy etap kryzysu (kwiecień 1953) wiązał się z odwołaniem premiera Khawaji Nazimuddina przez gubernatora generalnego Ghulama Muhammada, wbrew obyczajowi systemu westminsterskiego. Gdy w odpowiedzi konstytuanta ograniczyła uprawnienia gubernatora generalnego, ten w październiku $1954 \mathrm{r}$. bezprawnie ją rozwiązał. Zakwestionowanie tej decyzji na ścieżce prawnej skończyło się przed Sądem Najwyższym, który wiosną 1955 r. staną po stronie Ghulama Muhammada, konstruując dla uzasadnienia jego działań tzw. doktrynę konieczności. Kolejnym skutkiem przesilenia był wzrost politycznej roli wojska, którego głównodowodzący, Mohammad Ayub Khan, okazał się ostatecznie głównym beneficjentem tych przemian. Artykuł dowodzi, że główne powody kryzysu to 1) brak „naturalnego” przywództwa w kraju po śmierci Jinnaha i jego prawej ręki Liaquata Alego Khana, 2) oparcie ustroju na wzorcach brytyjskich, których fundamentem jest w znacznej mierze nieprzeszczepialna tradycja. Tekst poddaje pogłębionej analizie rolę Muhammada Munira, prezesa Sądu Najwyższego w latach 1954-1960: źródła (część z nich świeżo odtajniona) sugeruja, że świadomie współdziałał on z kolejnymi „silnymi ludźmi” Pakistanu, jeszcze przed objęciem urzędu skłaniając się ku ustanowieniu w kraju świeckiej autokracji.

\section{„I dream of God's Lion". The crisis of Pakistani policy in 1953-1955}

During the years of 1953-1955 the Pakistan's constitutional order, inherited from the times of its founding father Mohammed Ali Jinnah, was de facto effectively liquidated, paving the way for transition into autocracy in 1958. The crisis had three phases. First, Governor-General Ghulam Muhammad dismissed Prime Minister Khawaja Nazimuddin, breaking with the tradition of Westminster system (April 1953). Next, Ghulam Muhammad unlawfully dissolved the Constituent Assembly for trying to curtail his powers (October 1954). The last act was a legal battle before the Supreme Court, which sanctioned most of Governor-General's actions, employing for this purpose the so-called "doctrine of necessity" (Spring 1955). This also led to the great rise of army's influence in politics, and in the end it was its Commander-in-Chief, Mohammad Ayub Khan, who became the biggest beneficiary of the changes. The article argues that the most important factors which led to the crisis were: 1) the lack of "natural" leadership in Pakistan' ruling party after the death of Jinnah and his successor Liaquat Ali Khan, and 2) the fact that the state's institutional system was in many aspects copied from the British one, relying heavily on the non-transferable tradition. The role of Muhammad Munir, Chief Justice of the Supreme Court (1954-1960), is closely examined; the sources, many of them published or unclassified only recently, suggest that he was a willing fellow traveller of all the influential anti-democratic "strong men", being in favour of secular autocracy even before assuming this office.

\section{Bibliografia}

Ayub Khan M., Friends not Masters. A Political Autobiography, London 1967.

Baluch M.A.Y.K., Inside Baluchistan. A Political Autobiography of His Highness Baiglar Baigi, Khan-e-Azam-XIII, Karachi 1975.

Binder L., Religion and Politics in Pakistan, Berkeley 1963. 
Chief Justice Muhammad Munir. His Life, Writing and Judgments, ed. N.C. Chaudhry, Lahore 1973.

Constitution-Maker. Selected Writings of Sir Ivor Jennings, ed. H. Kumarasingham, Cambridge 2014.

Diaries of Field Marshal Mohammad Ayub Khan, 1966-1972, ed. C. Baxter, Karachi 2007. Dil A., Dil A., Bengali Language Movement and the Creation of Bangladesh, Dhaka 2011.

Fakhr-ul-Islam, Iqbal M., Islamizing the Constitution of Pakistan: The Role of Maulana Maudoodi, „Al-Idah”, XII 2013, no. 27.

Goodnow H.F., The Civil Service of Pakistan. Bureaucracy in a new nation, London 1964.

Hamid Khan, Constitutional and Political History of Pakistan, Oxford 2005.

Hamidul Huq Chowdhury, Memoirs. Autobiography, Dhaka 1989.

Hatch-Barnwell S., The Last Guardian. Memoirs of Hatch-Barnwell, ICS of Bengal, Dhaka 2011.

Ispahani F., Purifying the Land of the Pure. A History of Pakistan's Religious Minorities, New York 2017.

Jalal A., The State of Martial Rule. The Origins of Pakistan's Political Economy of Defence, Lahore 1991.

Kamal A., State against the Nation. The Decline of the Muslim League in Pre-independence Bangladesh, 1947-54, Dhaka 2009.

Karim S., Secular Jinnah \& Pakistan. What The Nation Doesn't Know, Karachi 2010.

Kiran N., The Federal Cabinet of Pakistan and Politics of East Bengal/Pakistan, 1947-1958, „IOSR Journal of Humanities and Social Science”, VIII 2016, vol. XXI, no. 8.

Kundi M.A., Ghulam Mohammad: His Life \& Work, „Journal of Political Studies” 2016, vol. XXIII, no. 2.

Kux D., The United States and Pakistan, 1947-2000. Disenchanted Allies, Washington 2001.

Lombardi C., Islamism as a Response to Emergency Rule in Pakistan: the Surprising Proposal of Justice A.R. Cornelius, w: Emergency Powers in Asia. Exploring the Limits of Legality, ed. V.V. Ramraj, A.K. Thiruvengandam, Cambridge 2010, s. 436-465.

McGrath A., The Destruction of Pakistan's Democracy, Karachi-Oxford 1998.

McIntosh S.C.R., Kelsen in the „Grenada Courts”. Essays on Revolutionary Legality, Kingston 2008.

Memoirs of Huseyn Shaheed Suhrawardy with a Brief Account of His Life and Work, ed. M.H.R. Talukdar, Karachi 2009.

Müller J.W., Przeciw demokracji. Idee polityczne XX wieku w Europie, tłum. J. Majmurek, Warszawa 2016.

Munir M., From Jinnah to Zia, New Delhi 1980.

Newberg P., Judging the State. Courts and Constitutional Politics in Pakistan, Cambridge 2002.

Niaz I., Jinnah on governance: The unheeded advice of Pakistan's Quaid-i-Azam, „Asian Affairs" 2016, vol. XLVII, no. 3.

Nikolić Z., Baker R.B., Between Politics and Science: The Dilemma of Reason, „The Journal Jurisprudence" 2014, vol. XXII.

Pirzada S.S., Dissolution of Constituent Assembly of Pakistan and the Legal Battles of Moulvi Tamizuddin Khan, Karachi 1995.

Qasmi A.U., The Ahmadis and the Politics of Religious Exclusion in Pakistan, London-New York 2014.

Riaz Ahmad, Pakistan's First Constituent Assembly's Efforts for the Making of Constitution, 1947-1954, „Pakistan Journal of History \& Culture” 2002, vol. XXIII, no. 1.

Rizvi H.A., The Military and Politics in Pakistan 1947-86, Lahore 1987.

Seyyed Vali Reza Nasr, The Vanguard of the Islamic Revolution. The Jama'at-i Islami of Pakistan, Berkeley 1994. 
Sheikh Mujibur Rahman, The Unfinished Memoirs, transl. F. Alam, Dhaka 2012.

Syed Sami Ahmad, Tamizuddin Khan's Case. The Judgment that Brought Disaster, Karachi 1991.

Tamizuddin Khan, The Test of Time. My Life and Days, Dhaka 1989.

Zaheer H., The Times and Trial of the Rawalpindi Conspiracy 1951. The First Coup Attempt in Pakistan, Karachi 1998.

Bi o g r a m: Tomasz Flasiński - mgr; w Instytucie Historii PAN przygotowuje pracę doktorską na temat życia politycznego Bengalu w latach 1945-1947. Jego zainteresowania badawcze dotyczą dwudziestowiecznej Azji Południowej ze szczególnym uwzględnieniem subkontynentu indyjskiego, a także Stanów Zjednoczonych pierwszej połowy XX w. Jest autorem tomiku wierszy Epikryzy (Kraków 2012). E-mail: radagajs@poczta.fm. 